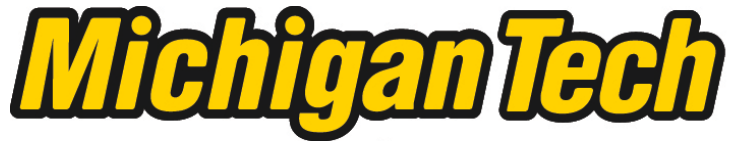 \\ Michigan Technological University Create the Future Digital Commons @ Michigan Tech
}

Dissertations, Master's Theses and Master's Reports - Open

Dissertations, Master's Theses and Master's

Reports

2011

Rural water system sustainability : a case study of communitymanaged water systems in Saramaka communities

Gwynneth Smith

Michigan Technological University

Follow this and additional works at: https://digitalcommons.mtu.edu/etds

Part of the Civil and Environmental Engineering Commons

Copyright 2011 Gwynneth Smith

\section{Recommended Citation}

Smith, Gwynneth, "Rural water system sustainability : a case study of community-managed water systems in Saramaka communities ", Master's report, Michigan Technological University, 2011.

https://doi.org/10.37099/mtu.dc.etds/518

Follow this and additional works at: https://digitalcommons.mtu.edu/etds

Part of the Civil and Environmental Engineering Commons 


\title{
RURAL WATER SYSTEM SUSTAINABILITY: A CASE STUDY OF COMMUNITY-MANAGED WATER SYSTEMS IN SARAMAKA COMMUNITIES
}

By

Gwynneth Smith

\begin{abstract}
A REPORT
Submitted in partial fulfillment of the requirements for the degree of

MASTER OF SCIENCE

Civil Engineering
\end{abstract}

MICHIGAN TECHNOLOGICAL UNIVERSITY

2011

(C) 2011 Gwynneth Smith 
This report, "Rural Water System Sustainability: A Case Study of Community-Managed Water Systems in Saramaka Communities", is hereby approved in partial fulfillment of the requirements for the Degree of MASTER OF SCIENCE IN CIVIL ENGINEERING.

Department of Civil and Environmental Engineering

Signatures:

Report Advisor:

John Gierke

Department Chair:

William Bulleit

Date: 


\section{Preface}

The motivation for this research came out of my experience while serving as a Peace Corps Volunteer for 26 months in Suriname, South America from May 2008 to July 2010. I worked as a community health education volunteer in the Saramaka village of Tutu Buka, on the Upper Suriname River. The work in my community was centered on water and sanitation issues and HIV/AIDS education. This project grew out of my observation of difficulties with water supply that I learned about over the course of my time in Suriname. This paper is derived from an investigation I conducted of three water supply systems in nearby Saramaka communities.

This report of that investigation is submitted to complete my master's degree in Civil Engineering from the Master's International Program in Civil and Environmental Engineering at Michigan Technological University. 


\section{Table of Contents}

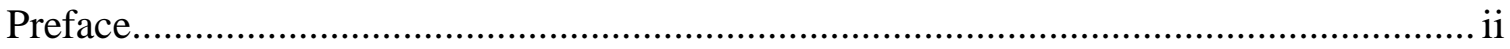

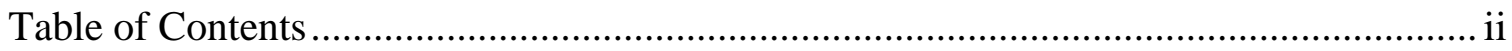

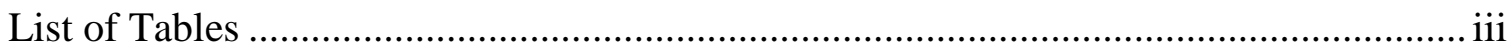

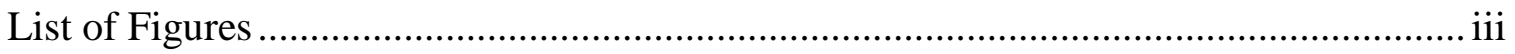

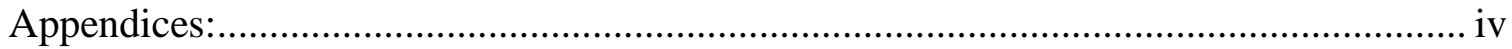

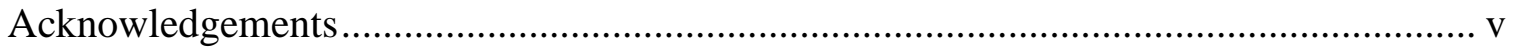

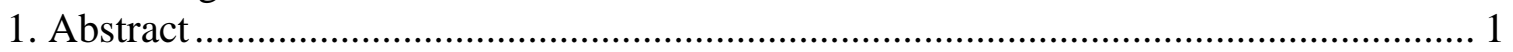



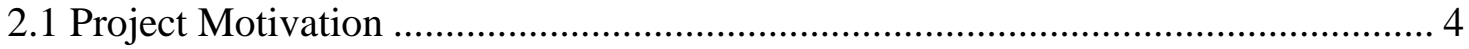

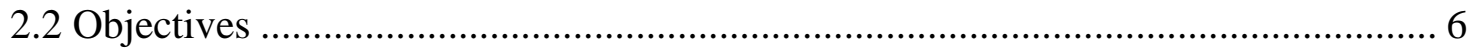

3. Project Site: Saramaka, Suriname (N 4 ${ }^{\circ} 25^{\prime}$, W 55 $\left.5^{\circ} 22^{\prime}\right)$........................................... 7

3.1 Life in Saramaka - Culture and Environment ............................................... 8

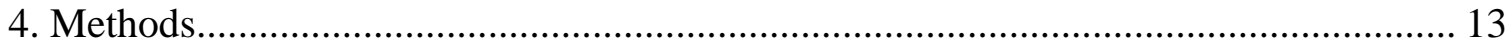

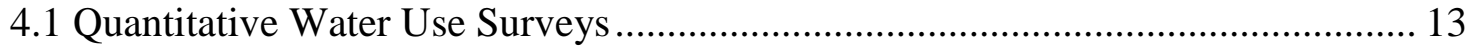

4.2 Qualitative Surveys of Community Perceptions ............................................ 14

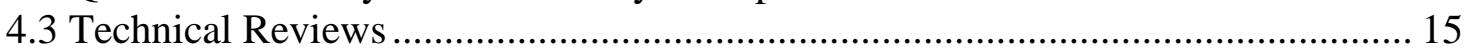

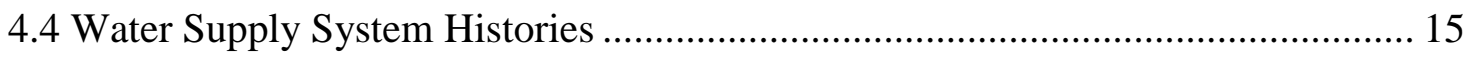

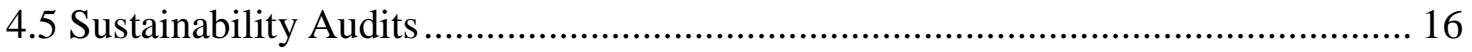

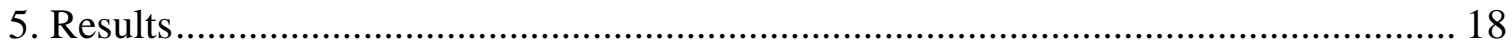

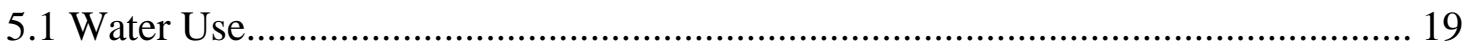

5.2. The Water Supply Systems - An Overview ....................................................... 22

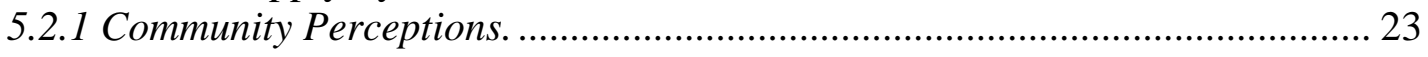

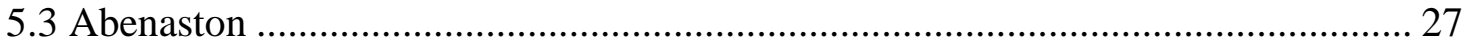

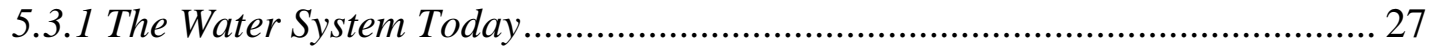

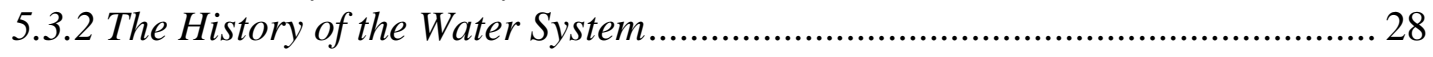

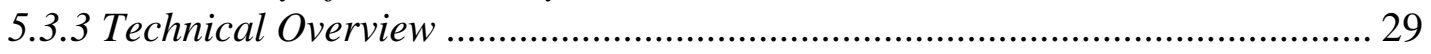

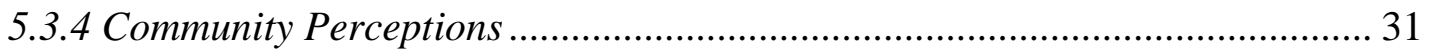

5.3.5 Sustainability Assessment - Abenaston ……............................................. 31

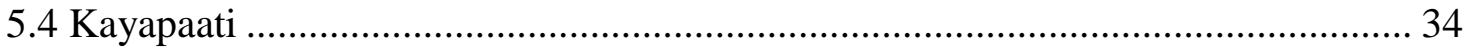

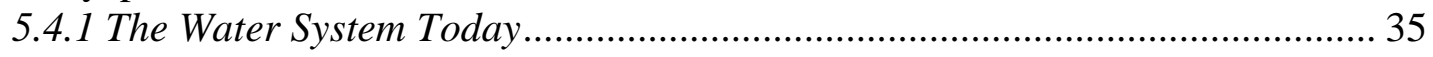

5.4 .2 The History of the water system ............................................................. 35

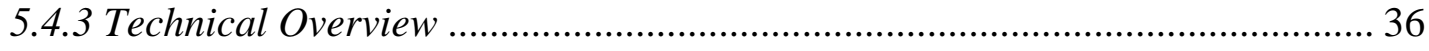

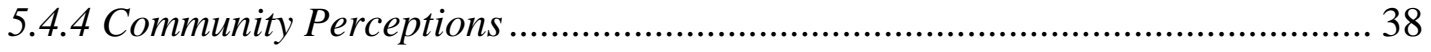

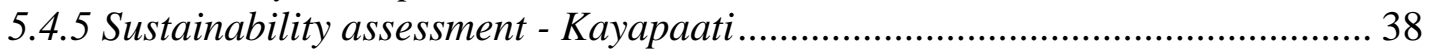

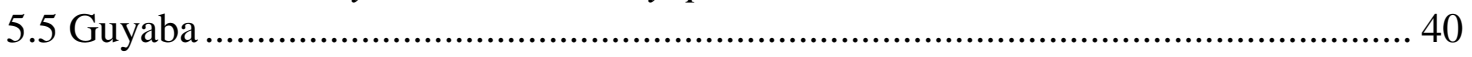

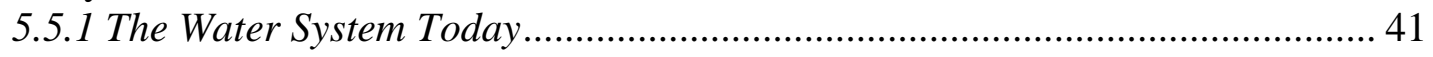

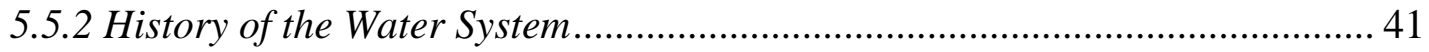

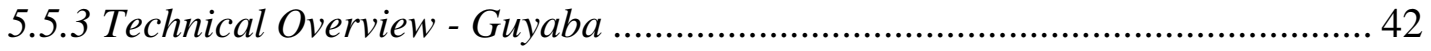

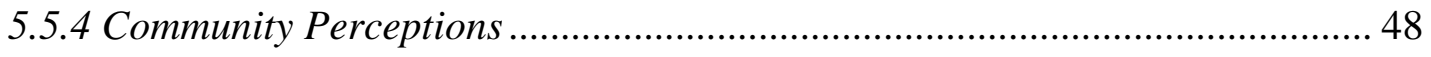

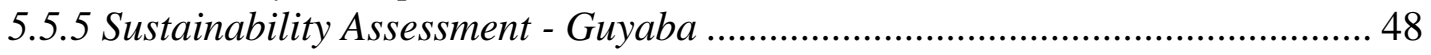

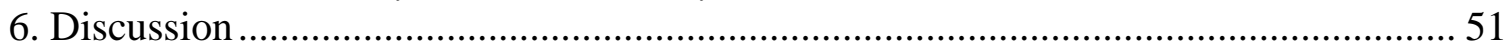

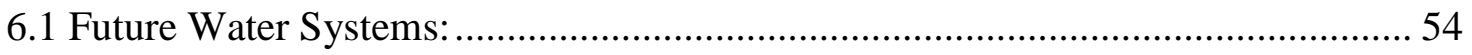

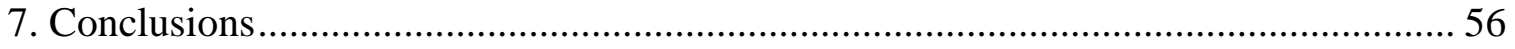

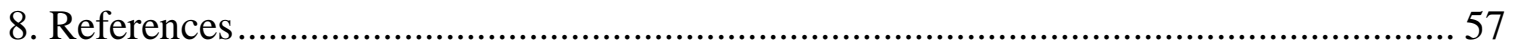




\section{List of Tables:}

Table 1 An overview of which standard features of a rural water supply project as given by Kleemeier (2000) were included for the three communities. .............................. 3

Table 2 Interviews conducted in the three communities. See Appendix A for the complete

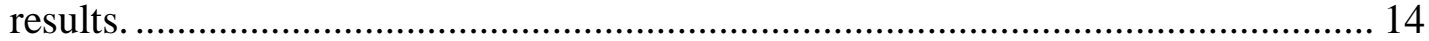

Table 3 Summary of water use survey results (Guyaba). The data used to calculate these totals can be found in Appendix E...................................................................... 21

Table 4 Summary of the qualitative survey results on community perceptions.............. 26

Table 5 The specifications for the water supply system in Abenaston, as observed at the time of the evaluation in May 2010 .................................................................... 30

Table 6 The results of the sustainability assessment matrix (McConville and Mihelcic

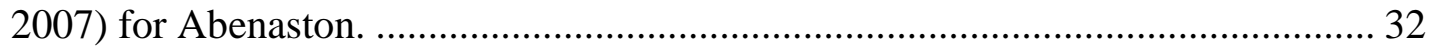

Table 7 The specifications for Kayapaati's water supply system as observed at the time of the evaluation in May 2010 ............................................................................ 37

Table 8 The results of the sustainability assessment matrix (McConville and Mihelcic

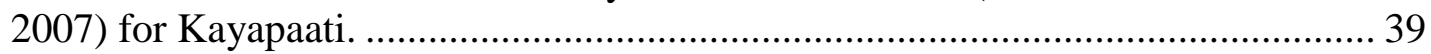

Table 9 The specifications of the water supply system in Guyaba as observed at the time

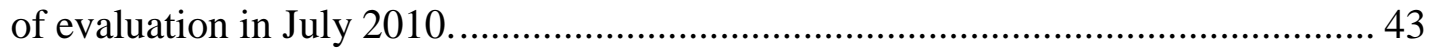

Table 10 Water available per person at various operating conditions. ........................... 48

Table 11 The results of the sustainability assessment matrix (McConville and Mihelcic 2007) for Guyaba.

\section{List of Figures}

Figure 1. Map of Suriname, South America (adapted from Database of Global Administrative Areas(Hijmans et al. 2009)) and the three study communities located on the Upper Suriname River. .................................................................... 8

Figure 2. An agricultural plot in Kayapaati with cassava and vegetables, ready to be



Figure 3. Sustainability assessment matrix developed by McConville and Mihelcic (2007) (used with permission)................................................................................ 16

Figure 4. Saramaka people at midday using the Upper Suriname River for bathing and washing. ............................................................................................. 20

Figure 5. A typical polyethylene water storage tank in a Saramaka community. ........... 20

Figure 6. Abenaston as seen from the air. The river flows from bottom to top............... 27

Figure 7. The intake for the water system at the time of evaluation, May 2010. The weir can be seen along with the gravel bed covering the intake in the center of the photo. The pyramidal structure in the left of the photo is the original slow sand filter...... 29

Figure 8. The pump performance curve and system curve show that the pump is capable of flows approximately of 5 gallons per minute to the water storage tanks. ............. 30

Figure 9. Kayapaati from the air. The river flows from right to left. The creek which serves as the water source for the community discharges to the left and outside of the picture frame, and the creek itself is not visible due to the vegetation. 34 
Figure 10. Kayapaati Creek in the dry season (left) and the rainy season (right). In the right photo the water is waist deep if standing on the submerged section of the log.

Figure 11. The water tower in Kayapaati and its polyethylene storage tanks................. 36

Figure 12. The pump performance curve and system curve show that the pump is capable of flows approximately of 8 gallons per minute to the water storage tanks. ............ 37

Figure 13. Guyaba from the air. River is flowing from left to bottom right.................... 40 Figure 14. The water project donor monument board. It says "Clean Water For Life" across the top. The faucet below is dry................................................................ 42

Figure 15. The pump performance curve for Grundfos pump $40 \mathrm{SQF}-3$ (from the

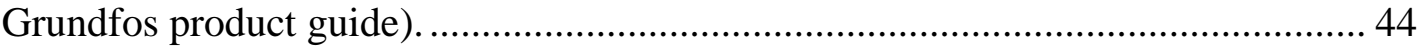

Figure 16. Potential System Operating Points for various wattages for pump model

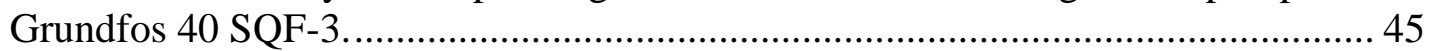

Figure 17. The calculated relationship between the wattage delivered to the pump and the resulting pump flow. ........................................................................................ 46

Figure 18. Calculated pump flow for the Grundfos 40 SQF-3 pump with an array of six solar panels at various times of day based on solar radiation received on 12/21/10.46

Figure 19. Flow for the Grundfos 40 SQF-3 pump and an array of six solar panels on a partly cloudy day. 47

Figure 20. One of the solar panel arrays and cloud cover on April 11, 2009. 47

\section{Appendices:}

All appendices are electronic.

Appendix A: Compiled results of community perception survey results. Appendix B: Calculations for technical reviews of water systems Appendix C: Verbatim transcriptions of community perception surveys Appendix D: Full checklists of sustainability audits (McConville 2006) Appendix E: Results of sustainability audits for Abenaston, Kayapaati, and Guyaba Appendix F: Results of water use survey (Guyaba) 


\section{Acknowledgements}

This report is the culmination of two beautiful and wild years living with the Saramaka people in central Suriname, South America. Many people have helped contribute ideas and direction for this study, and helped provide valuable context for the idiosyncrasies of development work. Many others have provided the emotional and physical support to finish this study. I would like to dedicate this paper to the strong and fabulous ladies of Saramaka.

Giving thanks, or tangi, is an important part of Saramaka culture, so first I would like to give tangi to the many Saramaka who befriended me during my time there. My great friend Mna Jozuazoon and her family helped turned Suriname from a strange place to a home. So many others have also shown me great kindness. Mi ke da gaan gaan tangi da hii dee tu. A de wan bigi sondi da'm.

I would also like to give tangi to my advisor, John Gierke, who not only braved the sweaty jungle and excruciating bus rides, but also helped show me that my work was of value, and held me to a higher standard. I would like to give tangi to my graduate committee, Carol MacLennan and Brian Barkdoll, for the advice and direction they provided.

I would also like to give tangi to my fellow Peace Corps Volunteers Temiemai, Opa Jack, and Hansepai, among the rest. Special thanks to Opa Jack and Hansepai for repeatedly ferrying me across the river in their dugout canoes during the fastest river flow days of the entire year.

Finally, I would like to give gaan gaan tangi to my parents and friends who have always been there for me. 


\section{Abstract}

Worldwide, rural populations are far less likely to have access to clean drinking water than are urban ones. In many developing countries, the current approach to rural water supply uses a model of demand-driven, community-managed water systems. In Suriname, South America rural populations have limited access to improved water supplies; community-managed water supply systems have been installed in several rural communities by nongovernmental organizations as part of the solution. To date, there has been no review of the performance of these water supply systems. This report presents the results of an investigation of three rural water supply systems constructed in Saramaka villages in the interior of Suriname. The investigation used a combination of qualitative and quantitative methods, coupled with ethnographic information, to construct a comprehensive overview of these water systems. This overview includes the water use of the communities, the current status of the water supply systems, histories and sustainability of the water supply projects, technical reviews, and community perceptions.

From this overview, factors important to the sustainability of these water systems were identified. Community water supply systems are engineered solutions that operate through social cooperation. The results from this investigation show that technical adequacy is the first and most critical factor for long-term sustainability of a water system. It also shows that technical adequacy is dependent on the appropriateness of the engineering design for the social, cultural, and natural setting in which it takes place. The complex relationships between technical adequacy, community support, and the involvement of women play important roles in the success of water supply projects. Addressing these factors during the project process and taking advantage of alternative water resources may increase the supply of improved drinking water to rural communities. 


\section{Introduction}

Of the 884 million people who lack access to improved water sources, $84 \%$ live in rural areas (UN 2009). Rural areas are typically remote, have small and dispersed populations, and few resources. The particulars vary greatly from place to place - there can be no onesize-fits-all solution - but the essential problem is the same: no reliable source of clean drinking water.

The Millennium Development Goals (MDGs) are a set of targets established by the United Nations to address worldwide poverty. Among these targets is the provision of clean drinking water: specifically, to "halve, by 2015, the proportion of the population without sustainable access to safe drinking water and basic sanitation" (UN 2009). This target has been a key factor in many governments and organizations undertaking efforts to improve drinking water access to urban and rural populations in the developing world.

The strategy taken by governments and other organizations to address the rural drinking water problem for the past few decades is known as the 'demand-responsive' approach. The basic principle of this approach is to treat water as an economic good, so that people receive the type and level of water services for which they are willing and able to pay (Kleemeier 2001; Whittington et al. 2009). Reductions in the size and functions of states that were caused by economic reforms have resulted in a reduction of the ability of governments to provide a minimum level of service to all citizens. Adopting a demandresponsive approach, where water users pay a share of the capital costs of their water infrastructure and all of the operation and maintenance costs, permits the government to take a more limited role in providing water services (Ferguson 2005).

In addition to diminishing the role that government is required to play in providing water services, the demand-responsive approach has also been seen as a solution to increasing the sustainability of water services by increasing community participation in and ownership of their water services (Isham and Kähkönen 1999). This communitymanagement model has been met with mixed reviews, as some studies laud the model for success (Whittington et al. 2009) and others criticize the model for being inadequate in dealing with long-term problems in operation and maintenance (Kleemeier 2000; Kleemeier 2001). The degree to which the community-management model has been adopted has varied; some programs attempt cost-recovery of the initial investment, while others have continued to provide outside support for operation and maintenance after construction has been completed. Table 1 gives an overview of the standard features of a community-managed rural water supply project as given by Kleemeier (2000), and which features of this model were incorporated in the water projects for the three study communities. 
Table 1 An overview of which standard features of a rural water supply project as given by Kleemeier (2000) were included for the three communities.

\begin{tabular}{|c|c|c|c|}
\hline Project Feature & Abenaston & Kayapaati & Guyaba \\
\hline $\begin{array}{l}\text { Meetings to explain project before it begins, community has right } \\
\text { to refuse it }\end{array}$ & & Y & $\mathrm{Y}$ \\
\hline $\begin{array}{l}\text { Contract signed specifying community's and project's } \\
\text { responsibilities }\end{array}$ & & $\mathrm{N}$ & $\mathrm{N}$ \\
\hline $\begin{array}{l}\text { User committee formed with design and construction } \\
\text { responsibilities }\end{array}$ & & $\mathrm{N}$ & $\mathrm{Y}$ \\
\hline Same committee or new one assumes O\&M responsibilities & $\mathrm{Y}$ & $\mathrm{Y}$ & $\mathrm{N}$ \\
\hline $\begin{array}{l}\text { Community upfront cash collection (to contribute to capital costs, } \\
\text { establish O\&M fund, or both) }\end{array}$ & $\mathrm{N}$ & $\mathrm{N}$ & $\mathrm{N}$ \\
\hline Community provides free labor and other materials & Y & $\mathrm{Y}$ & $\mathrm{Y}$ \\
\hline $\begin{array}{l}\text { Management and book-keeping training provided to committee } \\
\text { members; management procedures established }\end{array}$ & $\mathrm{N}$ & $\mathrm{N}$ & $\mathrm{N}$ \\
\hline Technical training and tools provided to local repair persons & Y & $\mathrm{Y}$ & $\mathrm{Y}$ \\
\hline Hand over ceremony & $\mathrm{Y}$ & $\mathrm{Y}$ & $\mathrm{Y}$ \\
\hline A staff of community mobilizers to carry out the above activities & Y & $\mathrm{Y}$ & $\mathrm{N}$ \\
\hline $\begin{array}{l}\text { Simple Technologies (VLOM handpumps, gravity schemes, } \\
\text { protected springs, etc.) }\end{array}$ & & $\mathrm{Y}$ & $\mathrm{N}$ \\
\hline
\end{tabular}

The community-managed model for water supply projects has been in use for a few decades and many of the water systems resulting from these projects have later been evaluated. Although this evaluation may seem straightforward, "how one defines the performance of rural water projects is somewhat more complicated than one might imagine (Whittington et al. 2009), as the current status of a water system may be located anywhere on the spectrum between total breakdown and the delivery of clean, plentiful, reliable water service. In the evaluations, several approaches have been used to determine which factors are most critical to water supply systems' long-term sustainability.

McConville and Mihelcic (2007) have developed a sustainability assessment tool for evaluating water and sanitation projects using holistic, life-cycle thinking. By evaluating the entire life-cycle of the water or sanitation project, and not simply the end results, the life-cycle approach creates an assessment tool that is unique. This approach provides insight into the many factors during planning, design, and implementation that affect the sustainability of a water system as well as the actions taking place during the ongoing operation and maintenance stage of the project.

This report uses the sustainability assessment tool from McConville and Mihelcic (2007) to complement qualitative and quantitative methods of data collection in investigating the functioning status of three water systems in rural communities. Community water supply systems are engineered solutions that operate through social cooperation. The results from this investigation show that technical adequacy is the first and most critical factor for long-term sustainability of a water system. It also shows that technical adequacy is dependent on the appropriateness of the engineering design for the social, cultural, and natural setting in which it takes place. The complex relationships between technical adequacy, community support, and the involvement of women play important roles in the 
success of water supply projects. Addressing these factors during the project process and taking advantage of alternative water resources may increase the supply of improved drinking water to rural communities.

\subsection{Project Motivation}

Suriname can be divided into three main population groups: the urban capital of Paramaribo and its suburbs, the coast, and the interior jungles. There is a vast degree of inequity in water supplies between the three areas of Suriname, with drinking water available to $92.6 \%$ of people living in urban areas, $66.6 \%$ of people living in the coastal region, and to just $20 \%$ of the people living in the interior of the country. Water supplies in the interior are overseen by the Ministry of Natural Resources instead of the Suriname Water Company (IDB 2008; PAHO 2010). Although there are a few community water systems managed by the Ministry of Natural Resources, the majority of Saramaka communities do not have access to improved sources of drinking water. To fill this gap, nongovernmental organizations (NGOs) and other organizations have stepped in with a variety of interventions ranging from slow-sand filters for households to water systems constructed using the demand-driven, community management model. This model is rooted in the demand-responsive approach in which water is treated as an economic good. In water projects that follow this model, the communities are responsible for part or all of the capital investment to build the water system, and all of the subsequent operation and maintenance costs, paid for with user fees. In Suriname, where it is referred to as the Botopasi model, this model is currently endorsed by the government of Suriname for water supply in the interior. In Saramaka, the typical initial community contribution ranges from $15-25 \%$ of the total project costs, paid for with labor and materials but not cash. All operation and maintenance is solely the responsibility of the communities. Table 1 (above) gives a summary of which features of a standard rural water supply project (Kleemeier 2000) were applied to the three communities being investigated.

The initial motivation for an investigation of the status of water systems in Suriname came from my time as a Peace Corps community water engineering specialist volunteer. During my time living and working in Saramaka communities I observed that few of the water supply systems in the interior of Suriname appeared to be working. In anecdotal information from other areas in the interior it was reported that the problem was widespread. The prevailing narrative about these systems from local development groups and the government was that these systems were not functioning due to the communities' lack of proper operation and maintenance. A report issued by the Ministry of Natural Resources (2008)states the problem with the failed water supply systems as such: "In the end the community has not been fully empowered and will not take enough of their own responsibility. With limited sense of ownership communities have been proven not to be able to facilitate capital development and technical capability for maintenance." However, other signs indicated that the problem was not necessarily the community, but the technical failure of the water supply systems. In order to make progress in providing reliable sources of clean drinking water to the rural populations of Suriname, I undertook this investigation to better understand first how well these systems were succeeding in 
supplying water, and, second, how technical adequacy and social factors contribute to the sustainability of the water systems. 


\subsection{Objectives}

Community-managed water supply systems are commonly chosen as an intervention to improve access to clean drinking water in rural communities in Suriname. However, without knowing about the performance of previously constructed systems, there is no information available to guide or improve future projects. Community-managed water supply systems are engineered solutions to providing clean drinking that depend on community participation, support, and willingness-to-pay to operate successfully. Understanding how technical adequacy and social factors each contribute to the sustainability of the water system allows both engineers and social workers to design better solutions for water resource development. Accordingly, the framework for this research was developed to address two primary objectives specific to water development in the interior of Suriname and yet include broader implications for system sustainability, the results of which might be transferable to other developing countries.

Objective 1: Determine the current status and past performance of three community-managed, rural, water supply systems in Saramaka communities in Suriname.

\section{Objective 2: Compare the roles of technical adequacy and social factors in determining the long-term sustainability of water supply systems.}

These objectives were addressed through a combination of oral interviews of different community stakeholders regarding their water use and perception of water systems, including public, donor, and governmental responsibilities, a somewhat objective sustainability audit of the water project development and implementation, and an evaluation of the technical adequacy of the existing system. 


\section{Project Site: Saramaka, Suriname (N $4^{\circ} 25^{\prime}$, W 55 $5^{\circ} 2^{\prime}$ )}

Suriname, sometimes known as "the beating heart of the Amazon", is the smallest country in South America, located just north of Brazil on the continent's northeast coast (Figure 1). Suriname's population lives in three main areas of the country: the urban capital, the coastal region, and the interior tropical rainforests. The population in the interior is primarily made up of Maroons, the descendants of slaves that escaped from sugar cane plantations in the $18^{\text {th }}$ and $19^{\text {th }}$ centuries. There are six tribes of Maroons in Suriname, and all are marginalized populations which rarely receive government attention unless it is in regards to the natural resources in areas they inhabit. The secondlargest maroon tribe, the Saramaka, have been negatively impacted by the government's development of natural resources in their territory. In 1965, the Saramaka lost half of their historical territory to the reservoir created by the Afobaka dam on the Upper Suriname River (Figure 1), which was built to provide energy to the aluminum processing industry and to the capital. More recent gold mining concessions in their territory have resulted in the second relocation of several villages that were impacted by the dam. Until the recent verdict of the land-rights case of Saramaka vs. Suriname, handed down by the Inter-American Court of Human Rights in 2008, the government was routinely giving concessions to international logging companies in Saramaka agricultural and hunting grounds (Price 2011).

The three Saramaka communities of Abenaston, Kayapaati, and Guyaba are located in the interior of the country, in the region known locally as Saramaka (see Figure 1). All three communities are located on the banks of the Upper Suriname River, within ten miles of each other. They are small communities, with 200-300 people each in Abenaston and Kayapaati, and 2500 in Guyaba. The interior of the country is covered in densely forested lowland tropical rainforest, with virtually no roads for access. 


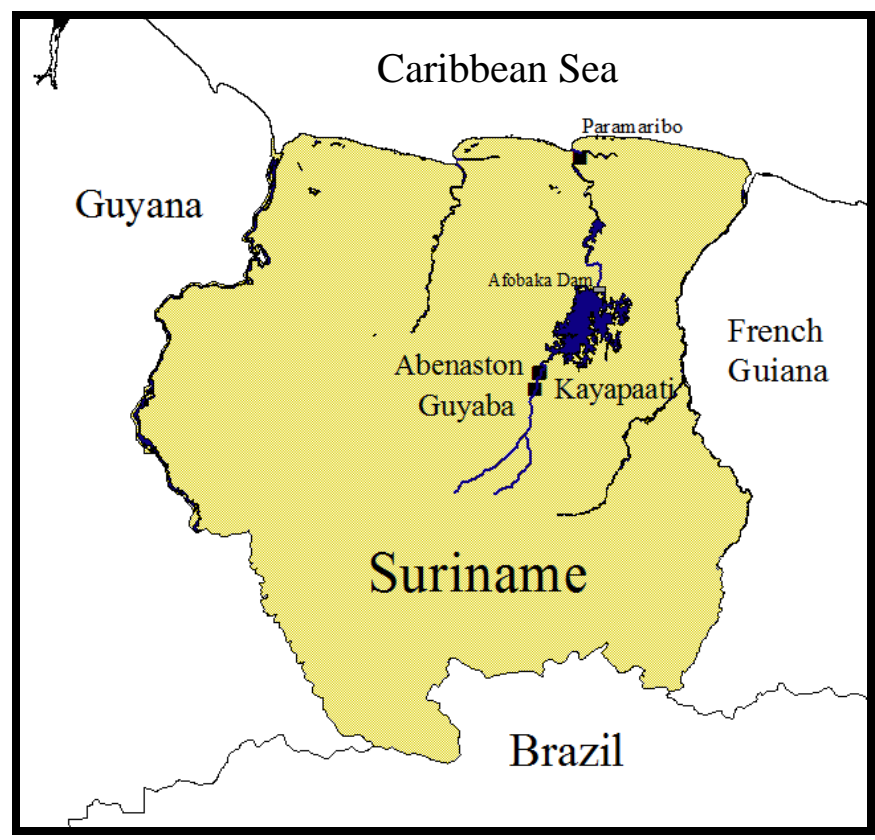

Figure 1. Map of Suriname, South America (adapted from Database of Global Administrative Areas(Hijmans et al. 2009)) and the three study communities located on the Upper Suriname River.

\subsection{Life in Saramaka - Culture and Environment}

The Saramaka people, including those from these three communities, depend on subsistence agriculture (Figure 2) and forest products for the bulk of their daily needs; their traditional lifestyle is intimately intertwined with the thick depths of forest that surround them. The riverside villages are densely packed, maze-like conglomerates of small wooden houses, either thatched or roofed with galvanized corrugated sheet metal, with dirt or cement floors. As there are no roads that extend through Saramaka territory, all villages are located along the Upper Suriname River which is the main avenue of transportation for the region. The villages are also often located near continuously flowing creeks and springs that supplement water supply from rainfall and the river.

Although it is the men who do the hard labor of clearing forest for the agricultural plots, it is the women who are the farmers and many spend a great deal of time at their plots (see Figure 2). These plots may be quite close to the village, but some are reachable only after hours of travel by canoe or jungle path. This is especially true in larger villages, such as Guyaba, where growing populations and the need to let land lie fallow between periods of cultivation has pushed the plots farther and farther out. These plots provide the bulk of the food for a household and are planted in rice, cassava, yams, sweet potatoes, bananas, taro root, and corn, as well as vegetables like pumpkin, bitter melon, eggplant, cucumber, and local greens. The abundant rainfall allows for two growing seasons a year. Plots are first cut, then burned, after which they are used for two to three years. Trees that are removed from the plot are used for construction, dugout canoes, and firewood. In this method garden plots provide for both the staples of the household and the means to cook them. The plots are assigned to families by the captains of the village, who are 
responsible for evenly rotating plots so that no area is cultivated too frequently and that land is distributed equitably.

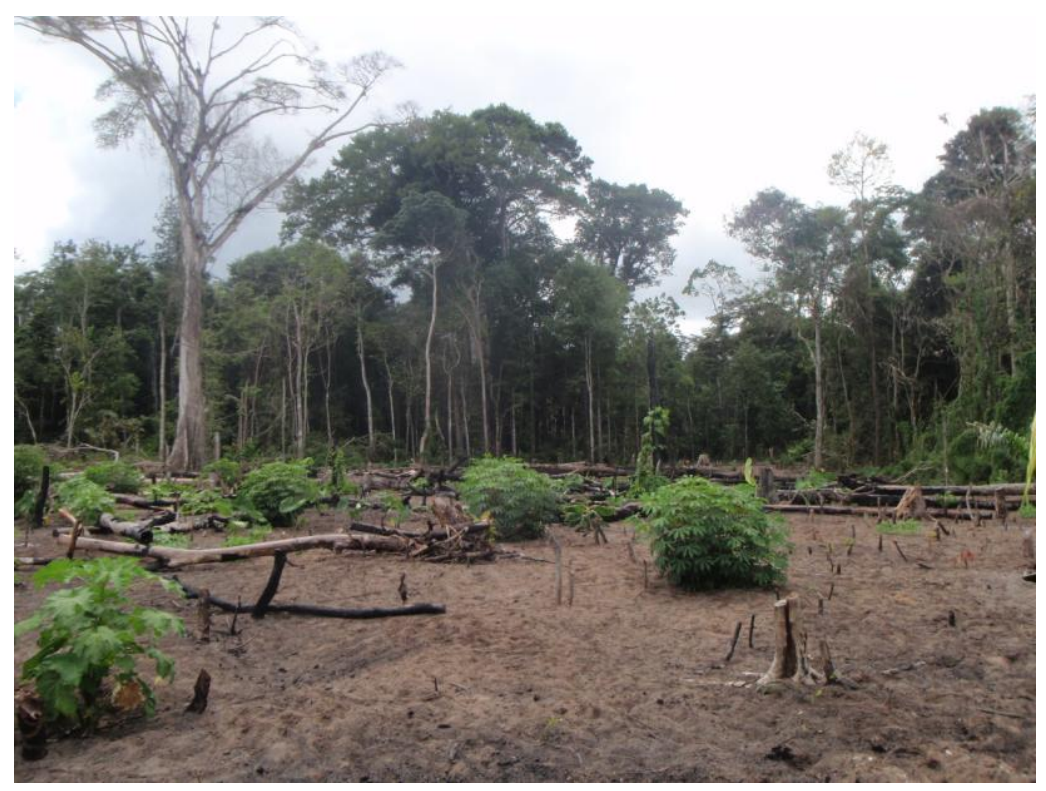

Figure 2. An agricultural plot in Kayapaati with cassava and vegetables, ready to be planted in rice.

The bulk of their agricultural production is for consumption within the family, but women sometimes plant peanuts for sale in Paramaribo. Clandestine marijuana production is done mainly by men.

There are no markets within the villages, and family groups are largely self-sufficient. Some women work for extra cash by sewing clothes, baking bread, working on other women's farms, or making crafts for tourists. The median cash income of maroon women in Suriname is just $\$ 40$ for the year (Heemskerk et al. 2004).

While the women are responsible for feeding the family, the men are expected to be wage earners. There are few opportunities in the villages for wage work, so the majority of the men travel to the capital or French Guiana to work in construction or odd jobs, or to work in the artisanal gold mines outside of the region. From the capital the men bring back the essential household goods which cannot be grown or obtained from the jungle, such as pots and pans, farming tools, salt, sugar, kerosene, fabric, and soap.

The Saramaka community has been largely insular since the tribe's formation in the late 1800's. The tribe suffered a brutal intrusion to their autonomy in 1965 after the completion of the Afobaka dam on the Upper Suriname River. Built to provide electricity for Suriname's aluminum smelting industry, the reservoir created by the dam flooded fully half of traditional Saramaka territory, displacing over 6000 people. Some people chose to move to relocation villages built by the government downstream of the dam, but many villages moved upstream to rebuild on their own. Kayapaati, which was known as Ganze before relocation, is one of these communities. For a great many Saramaka people, 
the flooding of their ancestral lands, burial grounds, homes, and holy places is a trespass still vividly remembered (Price 2011).

The takeover of their territory by the reservoir only added to the deep-seated mistrust that Saramakas have of outsiders and even of each other. "The fear of group betrayal, forged in slavery and the decades of war, remains the cornerstone of the Saramaka moral system. Proverbs and folktales are filled with morals about not trusting other people, and selfdefense posturing and manipulation permeate interpersonal relations... with outsiders, as would be expected, deception and prevarication become very much a matter of course" (Price 1983).

These attitudes have significant repercussions for development work done in Saramaka communities. Saramakas who work with development agencies and NGOs usually assume that the project is being done for the agency's profit. The extensive record of failed projects throughout the region (as is common in many developing countries) has only encouraged this sentiment. Communities are often suspicious that the mandatory community contributions included in projects are simply for increasing the profit margins of the development agencies.

The construction of the dam was the first large intrusion into traditional Saramaka life, but the construction of Afobaka Road, which provides greater access to the region, and the introduction of cell phones has greatly increased Saramaka interaction with the outside community. The roads and cell phones have also facilitated the movement of the Saramakas themselves. The Saramaka population today is around 50,000, but a third live in French Guiana and many others reside in Suriname's capital, leaving about half in the villages (Price 2001).

The extensive network of Saramakas outside their traditional territory and the amount of travel between the regions has led to curious duality in Saramaka life, with many people switching back and forth between Western city lifestyles and customary village life. Families that live in the capital still maintain homes in the villages. During school vacation those living in the city come to the villages, and those in the villages often head to the city, drastically changing the appearance of the community for a few weeks. On important holidays or religious ceremonies, village populations can double. Coupled with the practices of people camping at their agricultural grounds for long periods of time, visiting other villages to stay with spouses or relatives, and teenagers leaving the village to attend secondary school, it is difficult to get a real estimate of the number of people living in a village at any given time.

This increased and frequent interaction with more western society has had an impact on Saramaka society. House styles are changing to reflect the building styles of the coast. Washing machines and flushing toilets with septic tanks are making their way into more affluent households. Although women dress traditionally, only a few men still wear traditional Saramaka clothing. The construction of airstrips, the proliferations of tourists and tourist camps, and legal battles over land rights are just a few more of the rapid changes in Saramaka society over the past few decades. 
This tension between western and Saramaka values is apparent in Saramaka family structure, most notably in communities that have converted to Christianity such as Abenaston. In these communities, traditional Saramaka family structure, which is matrilineal and polygynous is occasionally rejected for a patriarchal family organization (though rarely a monogamous one), which can lead to confusion about familial obligations in extended families. For all communities marriages are often inter-village unions to avoid marrying relatives, and it is not uncommon for men to maintain wives in three separate villages at once, moving from place to place to spend time with each. Differences in roles and resources available to each gender give a transactional flavor to marital relations, as each partner maintains distinctly separate households. As Richard Price puts it:

"Even standard service rights are not given absolutely in the marriage contract. A man has rights to domestic services (cooking, housekeeping, washing, and so forth) as well as to a large share of his wife's horticultural produce; a woman expects economic support houses, canoes, and other items manufactured by her husband, goods he buys on the coast, hunting and fishing kills, and certain kinds of agricultural labor. But all such services continue to be sought by each partner's consanguines [blood relatives], so that there is a continual tension throughout marriage between a person's spouse and his consanguines, competing for his time and energy." (Price 1974)

The permanent family ties form critical parts of the social support network that Saramakas build for themselves. However, women typically go to greater lengths to preserve a marriage because:

"For a woman, being poor is synonymous with being unmarried, since only a husband ever adequately provides her with city-bought goods, cleared horticultural plots, and hand-fashioned products such as canoes. Because of this dependence, most women view a bad marriage as preferable to no marriage at all."(Price 1974)

The division of economic roles led to economic vulnerability of Saramaka women in 1974, when Price published his ethnography, but the continued isolation of women from participation in the outside economy has increased this vulnerability. Basic goods and services, such as a primary education for their children or a steady supply of clean water, must be paid for with cash in the form of school fees and water payments. The itinerance of Saramaka men, both within the region and outside of it, places the burden of routine infrastructure costs on the women, the population least able to pay them.

The most vulnerable population in the villages are old, whether they are men or women. Social security-type payments are available to those over 60 , but the small payments of $\$ 36 /$ month are infrequent and susceptible to political manipulation. Another vulnerable population is composed of those Saramakas who are mentally or physically handicapped, who are often sent to the village to be cared for by relatives. Support of these various vulnerable people can place great strains upon the able-bodied members of the community. For example, one Saramaka couple I knew was supporting her 92-year-old 
father, his 86-year-old mother, two physically and mentally handicapped sons in their thirties, and two small granddaughters. Of their eight other able-bodied children, only one still resided in the village. This was a type of situation that many families in the region encounter.

In the face of many changes, Saramakas have maintained a strong sense of identity and community. However, a variety of factors (rapidly burgeoning population, increased population density from the relocations after completion of the dam, and changing lifestyle expectations) have created water and sanitation problems that did not previously exist. Addressing these issues and incorporating Saramaka values into solutions are just a few of the challenges in designing successful water supply systems for these communities. 


\section{Methods}

A primary goal of this investigation was to establish the actual status of the water systems in the Saramaka region and identify which factors were contributing to their successes or failures. Because there was little information available, this study took the form of an exploratory research project. Three water systems were chosen for evaluation in the communities of Abenaston, Kayapaati, and Guyaba. All three water supply systems had been constructed in the past five years and under the management of the same organization, the Paramaribo Chapter of Rotary Club International.

In order to provide a counter to the narrative produced by development organizations of failing community management, this evaluation utilized ethnographic methods. Ethnographic evaluations enable the inclusion of the world view of the participants in the investigation as well as providing some baseline values as context for the rest of the results (LeCompte and Goetz 1982). This approach is also most appropriate for determination of the causality of problems before more systematic survey research might investigate the extent of a problem. Information from participant observation and key informant interviews during the two-year span of my Peace Corps volunteer service was used to guide the content and format of the quantitative and qualitative surveys used in the investigation. After securing Human Subjects Research approval (Protocol No. M06 48) from the Office of Research Integrity and Compliance at Michigan Technological University, interviews were conducted in May and July of 2010. As part of a holistic, life-cycle approach to the investigation, histories of the project process are important to give insight into the challenges the water supply systems currently face in being sustainable. The background of the water system projects were compiled and used to interpret the results of the qualitative and quantitative methods.

The investigation consisted of five main parts: (1) quantitative water use surveys, (2) qualitative surveys on community perceptions of the water supply systems, (3) technical reviews of the systems, (4) histories of the water systems compiled from key informants, and (5) sustainability assessments using the tool developed by McConville and Mihelcic (2007).

\subsection{Quantitative Water Use Surveys}

A water use survey was conducted in all three communities with 19 participants from Abenaston, 19 participants from Kayapaati, and 26 from Guyaba. Revisions of the survey format during the investigation resulted in changes in the data sets produced from the three communities, which prevented compilation of all results. Information on water use habits and preferred water sources is drawn from the results of all three communities. The water use statistics were calculated from the results from Guyaba, which had the largest sample size. The results from Guyaba were consistent with the results from the other two communities. 
In Saramaka society, women are the primary household water managers; because of this, all participants selected for the survey were women. For the purposes of the survey, water use was broken into four categories: drinking and cooking water, bathing water, clotheswashing water, and dishwashing water. The water use categories used in the survey were based on observations of water use patterns in the communities. The water use quantities surveyed were measured in terms of the vessels used for the particular water category, e.g., three black pails, two large tubs. In order to create a more comfortable atmosphere and to verify the size of the vessels being used to quantify water use, I conducted the surveys at the participants' homes in an informal manner. The types of vessels used for the different categories in Saramaka households were consistent across the three villages which facilitated this method of quantification.

\subsection{Qualitative Surveys of Community Perceptions}

In order to establish perceptions of the water system in the communities, a qualitative survey was conducted using topical interviews. A total of 30 interviews were conducted with 63 participants overall from the three communities (see Table 2). The complete summary of the community perception survey results can be found in Appendix A. The three topics included in the interview were: 1) perceptions of/satisfaction with the community's water system, 2) willingness-to-pay, and 3) responsibility for the water system. The interviews were informal and open-ended to encourage participant input and conducted at the participants' residences. Interview size ranged from one to five participants, with the average interview consisting of two people.

Table 2 Interviews conducted in the three communities. See Appendix A for the complete results.

\begin{tabular}{lllll}
\hline & Number of & & \\
Community & Interviews & Men & Women & Total \\
\hline Abenaston & 9 & 12 & 12 & 24 \\
Kayapaati & 12 & 9 & 11 & 20 \\
Guyaba & 9 & 8 & 11 & 19 \\
Total & $\mathbf{3 0}$ & $\mathbf{2 9}$ & $\mathbf{3 4}$ & $\mathbf{6 3}$ \\
\hline
\end{tabular}

Interviews were conducted in Saramaka, the local language, and recorded. The recordings were subsequently transcribed verbatim into written documents. Transcribing was difficult because Saramaka is not a written language. I conducted all of the interviews, and I tested at advanced proficiency in the Saramaka language two months prior to the study. After transcription, responses were grouped by question and then collated to identify common answers and themes. (The verbatim transcriptions, grouping of responses by category, and rough translations of those responses can by found in Appendix C.) Patterns were compared across community and by gender where applicable. Interviews that included the village captain ${ }^{1}$ or water committee members are noted. Participants were selected based on their availability, willingness to be interviewed, and

\footnotetext{
${ }^{1}$ Village Captains are the traditional leaders of Saramaka communities. They do not have legal authority, but are endorsed by the national government with modest pay.
} 
geographical location, and to include community leaders and water committee members. This research was not designed to be generalized to a larger population, or for the findings to necessarily be representative of the distribution within the entire community or region. Rather, it was designed to illuminate patterns in responses and the range and nature of community perceptions.

Due to the difficulties of a lone researcher conducting these surveys, the surveys were limited in scope, and did not attempt to ascertain any demographic data of the participants outside of gender or participation in community leadership. Analysis was conducted using the Saramaka transcriptions; all quotes included herein were translated to English from the spoken Saramaka.

\subsection{Technical Reviews}

The water systems were assessed for technical adequacy using engineering analyses. In order to qualify as technically adequate, the systems had to meet certain criteria. First, the water systems must qualify as improved water sources under the guidelines set by the World Health Organization (WHO 2011). Second, it must be capable of providing the minimum amount of daily household water needs as found by the quantitative water use surveys. Finally, it must be in working condition. The assessments were limited to the power supply, pump performance, and tank capacity. The number of working taps for each water supply system could not be ascertained because none of the three water supply systems were being operated at the time of evaluation. The system head curves were calculated from the minimum flow required to overcome the head in the system. Head losses included in the hydraulic analysis were from the static lift from the water source to the elevation that it discharges to the storage tank, and from frictional head loss. The Hazen-Williams equation for steady pipe flow, which requires pipe lengths and equivalent pipe lengths for minor losses, a friction coefficient, and pipe diameters, was used to determine the frictional head loss. Head losses from pump intakes could not be determined from the information available about the water systems and assumed to be minor. The calculations and specification used for the technical review can be found in Appendix B.

\subsection{Water Supply System Histories}

The histories of the water supply systems from the time that they were conceived as projects to the time of the evaluation in May - July 2010 were compiled primarily through key informant interviews. These key informants included traditional community leaders, water committee members, and members of coordinating development agencies that had assisted in project design and implementation, and consultants for the implementing donor agency (Rotary Club - Paramaribo) that had experience from past projects. 


\subsection{Sustainability Audits}

The sustainability audits of the three water supply systems were conducted using a matrix tool developed by McConville and Mihelcic (2007) (see Figure 3). The elements in the matrix incorporated life-cycle analysis to create a framework for identifying strengths and weaknesses in all stages in the life of water and sanitation projects. This matrix tool was designed to be used either in project planning or for auditing the completed projects, as it was used in this report.

McConville and Mihelcic (2007) began by dividing a project into five life stages. They named these life stages: 1) needs assessment, 2) conceptual designs and feasibility, 3) design and action planning, 4) implementation, and 5) operation and maintenance. Each of these life stages were to be evaluated in terms of sustainability. To do this, they subdivided sustainability into five factors, which were: 1) socio-cultural respect, 2) community participation, 3) political cohesion, 4) economic sustainability, and 5) environmental sustainability. The life stages and sustainability factors were put together to create a matrix with twenty-five elements.

\begin{tabular}{|c|c|c|c|c|c|c|}
\hline \multirow[b]{2}{*}{ Life stage } & \multicolumn{6}{|c|}{ Sustainability factor } \\
\hline & $\begin{array}{c}\text { Sociocultural } \\
\text { respect }\end{array}$ & $\begin{array}{c}\text { Community } \\
\text { participation }\end{array}$ & $\begin{array}{l}\text { Political } \\
\text { cohesion }\end{array}$ & $\begin{array}{c}\text { Economic } \\
\text { sustainability }\end{array}$ & $\begin{array}{l}\text { Environmental } \\
\text { sustainability }\end{array}$ & $\begin{array}{c}\text { Total } \\
\text { possible score }\end{array}$ \\
\hline $\begin{array}{l}\text { Needs } \\
\text { assessment }\end{array}$ & 1.1 & 1.2 & 1.3 & 1.4 & 1.5 & 20 \\
\hline $\begin{array}{l}\text { Conceptual } \\
\text { designs and } \\
\text { feasibility }\end{array}$ & 2.1 & 2.2 & 2.3 & 2.4 & 2.5 & 20 \\
\hline $\begin{array}{l}\text { Design and } \\
\text { action } \\
\text { planning }\end{array}$ & 3.1 & 3.2 & 3.3 & 3.4 & 3.5 & 20 \\
\hline Implementation & 4.1 & 4.2 & 4.3 & 4.4 & 4.5 & 20 \\
\hline $\begin{array}{l}\text { Operation and } \\
\text { maintenance }\end{array}$ & 5.1 & 5.2 & 5.3 & 5.4 & 5.5 & 20 \\
\hline $\begin{array}{l}\text { Total possible } \\
\text { score }\end{array}$ & 20 & 20 & 20 & 20 & 20 & 100 \\
\hline
\end{tabular}

The matrix dimensions show five life stages of a water/sanitation development project and five factors of sustainability that cover environmental, economic, and societal issues. The possible score for each matarix coordinate is 4 . Totals indicate possible evaluation scores for each life stage or sustainability factor.

Figure 3. Sustainability assessment matrix developed by McConville and Mihelcic (2007) (used with permission).

Each element of the matrix was given four checkpoints. For example, for matrix element Row 2, Column 4 (economic sustainability, conceptual designs and feasibility) the four checkpoints are:

$\checkmark$ Estimate the implementation costs of each conceptual design.

$\checkmark$ Estimate operation, maintenance, and disposal costs for each conceptual design.

$\checkmark$ Assess the community willingness-to-pay in both monetary and non-monetary terms for each improved system. 
$\checkmark$ Conduct an economic feasibility assessment to evaluate long-term project viability based on cost estimates, projected operation and maintenance costs, community willingness-to-pay, the need for outside resources, and the availability of outside funding.

Each checkpoint is accompanied by questions to clarify the recommended actions. For example, for the first checkpoint above, the questions are:

- Are training costs included?

- How much will materials and equipment cost?

- What local materials can be used? What will it cost?

- How can non-local materials be obtained?

- What will transportation of materials, equipment, and laborers cost?

- What will labor cost? Skilled and Unskilled?

- Will food be provided for labor crews? What will it cost?

- Can community members provide local cost information?

- Will there be political fees that should be included in the budget?

- How should development workers' time be included?

- What about costs for promoting use of the system or health education? (McConville and Mihelcic 2007)

The complete checklists are provided in Appendix D.

This sustainability matrix was used to provide a somewhat objective way of evaluating the water supply projects for the three communities of Abenaston, Kayapaati, and Guyaba. Evaluating a project process five years after the fact by a researcher who had no personal involvement in the project, requires that in some cases assumptions had to be made about what may or may not have happened. The most fundamental assumption for the evaluation was that no significant changes in project management were made by the Rotary Club of Paramaribo during the time span in which they administered the three projects. Additionally, in instances where there was no indication that a particular action occurred, such as water quality testing or budget reviews, it was assumed that the action had not taken place. The use of these assumptions created some error in the scores produced in the sustainability audits. This error is further discussed in the results.

The sustainability audit scores for each community's water project are compared with the results of the observations and qualitative information collected in the other parts of this report. Strengths and weaknesses in the projects are discussed based on the audits, as well as how the elements audited have affected the project since the water supply systems' completions. 


\section{Results}

This section summarizes results of the water use survey and the investigations of the water supply systems in Abenaston, Kayapaati, and Guyaba. The investigation results are presented by community. A variety of methods, both quantitative and qualitative, were used for the water supply system investigations. The sustainability auditing tool by McConville and Mihelcic (2007) served as the blueprint for the extent and type of information collected in the investigations.

The sustainability audits produced by this tool provide a somewhat objective way of examining water supply projects. It allows for sustainability criteria to be consistently applied in order to produce a numerical score. The audit is comprehensive in that it addresses all aspects of sustainability, at all stages of the project life-cycle. However, the elements within the matrix used to generate scores are not weighted. Local culture or specific social settings can influence the relative weight of the elements in their contribution to long-term sustainability, and some matrix elements have a greater impact than other, equally weighted elements. This means that the numerical score produced by the matrix cannot be used to create objective rankings of the sustainability of several water supply projects. However, the use of the matrix in the audit provides a clear, objective way to identify differences between projects, and to identify specific shortcomings in the project process. The score also provides a measure of how well the project process adheres to principles which have been defined as necessary to achieve sustainability in the published literature (McConville and Mihelcic 2007). Water supply projects audited with this tool can be compared to projects in other places which have been previously evaluated using some or all of these sustainability principles. A summary of the detailed audit results are included in Appendix E

The ethnographic information collected for this report gives insight, nuance, and context to the results of the sustainability audit scores. This information complements the audit scores by helping show why low scores in certain sustainability factors or project stages had disproportionately large effects on the final outcomes of the water supply projects. The addition of ethnographic information to the sustainability audits permits subjective ranking of the importance of certain sustainability factors in this study area.

Finally, please not that the genders of people involved in the water supply projects, including the development workers, have been specifically mentioned in the results section. This is due to the impact of gender effects on sustainability that were observed in the water system investigations. During participant observation in Saramaka communities I witnessed the significant effect that gender had on interpersonal relations there. There is a Saramaka saying which goes: "Men and women are not friends" 2 . The implication behind this saying is that the sexual natures of men and women preclude friendship. Female development workers living in Saramaka communities according to Saramaka social norms would have necessarily had stronger and closer relationships to women in

\footnotetext{
${ }^{2}$ In Saramaka: womi ku muye an de mati.
} 
the community than to men. This is not to say that male development workers cannot effectively reach out to women in Saramaka communities. However, the involvement of female development workers would naturally increase women's involvement in the project, even without conscious or specific efforts to do so. The genders of other participants in the water supply projects were also important to the overall success of the water system; this is discussed later on in the paper.

\subsection{Water Use}

Cleanliness is a central tenet of Saramaka culture, which is reflected in the results of the water use survey. Dishwashing and laundry are chores that occur at least once daily, with a high standard of cleanliness expected in the output. Although Saramaka women cook predominantly over open fires, after each use pots are scrubbed to a mirror finish inside and out - the thick layer of soot removed with elbow grease and sand. No woman in any of the communities reported bathing less than three times a day. In order to maintain the socially expected level of cleanliness, Saramaka women avail themselves of the numerous water sources in the region.

All traditional Saramaka villages are located on the banks of the Upper Suriname River or its tributaries, and this serves as their most reliable water source (see Figure 4). Additionally, villages are typically located close to a spring or reliable creek. With over $2400 \mathrm{~mm}$ ( $~ 90$ inches) of annual rainfall, collection of rainwater provides a convenient source of household water during the two rainy seasons. Many people have set up rainwater-collection systems with large plastic tanks (400-600 gallons) collecting water from their roofs, but others simply set buckets and tubs under the eaves of their house (see Figure 5 for a picture of a typical storage tank). Collected rainwater is rarely conserved, with only one woman from all three communities reporting using water conservation to stretch stored rainwater through the dry seasons. A few women reported that their household of five could empty a 400 -gallon tank in just three days ( $<30$ gallons per person per day). Some people have homes constructed in the traditional Saramaka fashion with thatched roofs and very low eaves, which restricts the amount and quality of rainfall that can be collected. 


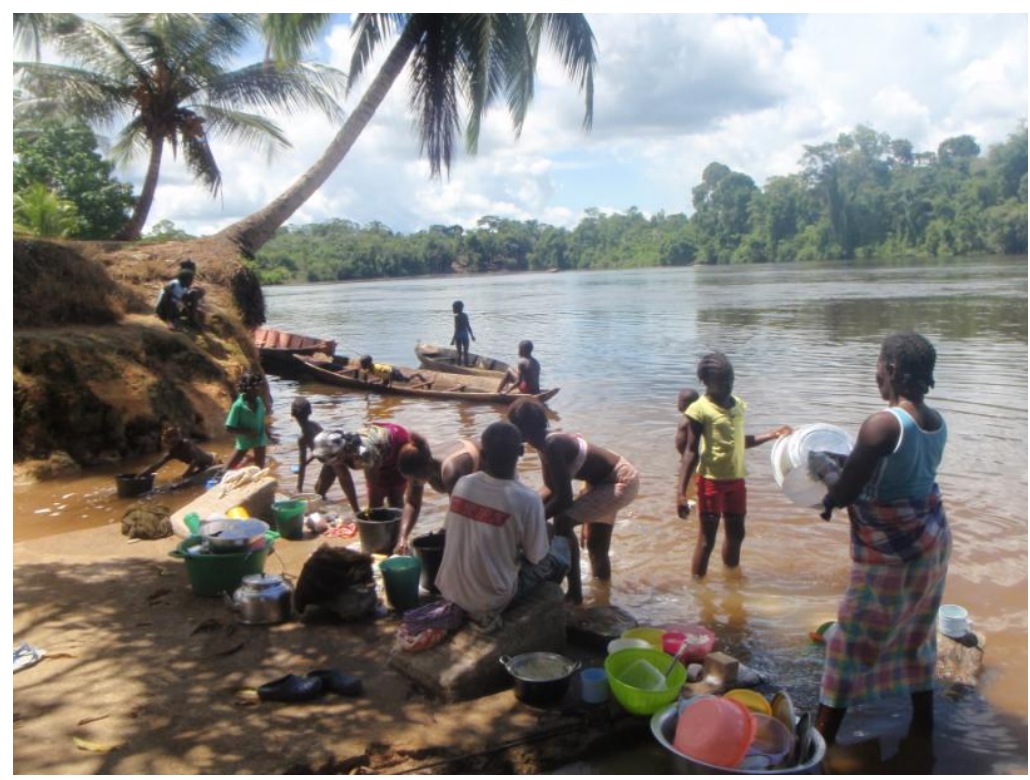

Figure 4. Saramaka people at midday using the Upper Suriname River for bathing and washing.

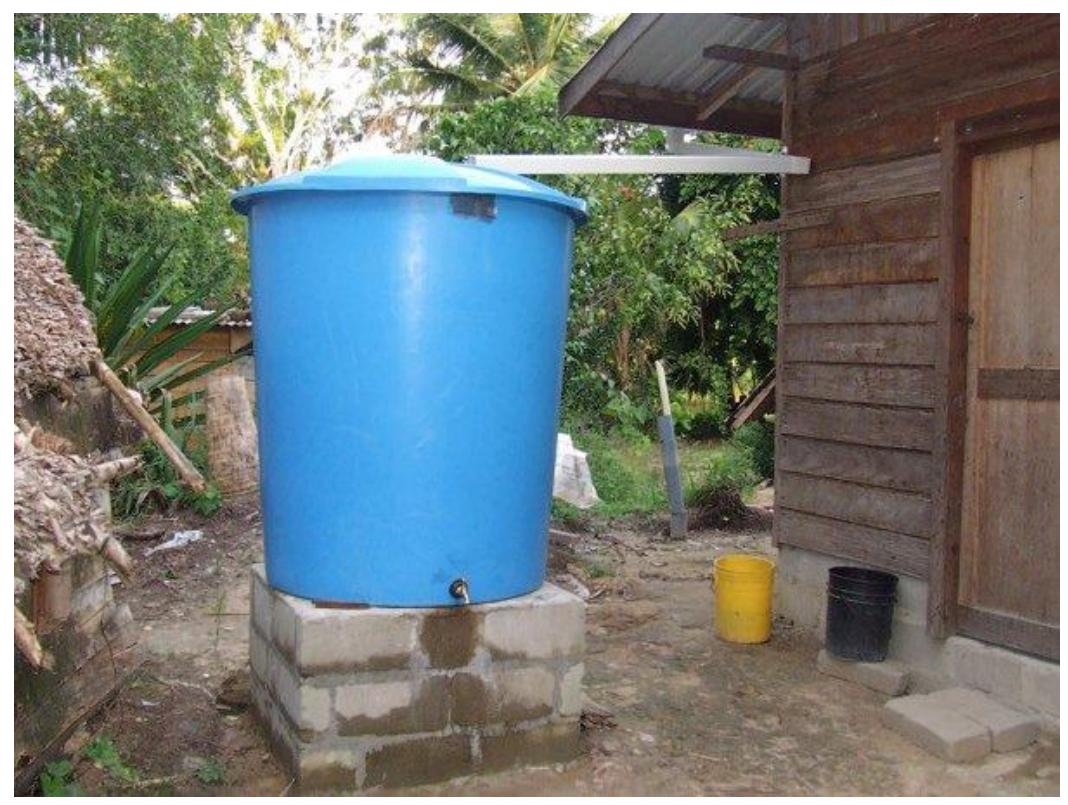

Figure 5. A typical polyethylene water storage tank in a Saramaka community.

The type of water source used in Saramaka households depends on both the season and the category of water use. The results from the water use survey showed that domestic water use in Saramaka falls into three basic categories: drinking \& cooking, bathing, and washing (clothes and dishes). For each category there are differences both in the traditionally preferred water sources and in the amount of water used at the household.

Drinking \& cooking water is always used at the household. Whether collected from rainfall or fetched from nearby springs or creeks, the water is then stored in buckets with lids for household use. The river remains the primary place of defecation for many people 
in the region and is considered unacceptable as a source of drinking water. River water was reported as a source of drinking water in the dry season only in Guyaba; this community does not have access to a reliable creek or spring.

Bathing occurs both at the water sources and at the household. During the rainy season many people prefer to bathe with rainwater, because the river water is full of organic material and causes skin irritation. In the dry season when rainwater is not available, most bathing occurs in the springs, creeks, and river.

Clothes and dishwashing are water-intensive activities and almost never performed away from the springs, creeks, or the river. Washing spots at these sources typically have stone outcrops or concrete steps, which are used as washboards, and the continuous flow of water makes it easier to rinse dishes and laundry. These tasks are performed at the household so infrequently that a few women simply refused to estimate the amount of water used for these tasks, insisting that they never performed these tasks except at the river. For this reason the estimates for washing water are less accurate than for other categories; they are included to give a baseline for total domestic water needs in a Saramaka household. Table 3 summarizes the results of the water use survey by category. The data used to calculate these totals can be found in Appendix F. If all the water consumed by a Saramaka household was used at the household, total daily water use would be almost 140 liters/person/day. With an average household size of 4.5 people, daily household water use would total more than 600 liters/household/day.

Table 3 Summary of water use survey results (Guyaba). The data used to calculate these totals can be found in Appendix E.

\begin{tabular}{|c|c|c|c|c|}
\hline \multirow{2}{*}{$\begin{array}{l}\text { Category of water } \\
\text { use }\end{array}$} & \multicolumn{2}{|c|}{ Traditional Preferred Water Sources } & \multirow{2}{*}{$\begin{array}{l}\text { Used at } \\
\text { household }\end{array}$} & \multirow{2}{*}{$\begin{array}{l}\text { Daily water use } \\
\text { (liters/person/ } \\
\text { day) }\end{array}$} \\
\hline & Wet Season & Dry Season & & \\
\hline $\begin{array}{l}\text { Drinking } \\
\text { Cooking }\end{array}$ & rainwater, springs & springs or creeks & always & 8 \\
\hline Bathing & $\begin{array}{l}\text { rainwater, springs, } \\
\text { creeks, or river }\end{array}$ & $\begin{array}{l}\text { springs, creeks, } \\
\text { or river }\end{array}$ & sometimes & 39.4 \\
\hline $\begin{array}{l}\text { Washing (clothes } \\
\& \text { dishes) }\end{array}$ & $\begin{array}{l}\text { springs, creeks, or } \\
\text { river }\end{array}$ & $\begin{array}{l}\text { springs, creeks, } \\
\text { or river }\end{array}$ & $\begin{array}{l}\text { almost } \\
\text { never }\end{array}$ & 89 \\
\hline
\end{tabular}

Total Daily Water Use (liters/person/day)

136.4

The minimum amount of water used daily at the household would allow for drinking and cooking as well as one bath at the house per day, which comes to 21 liters/person/day, or 94 liters/household/day. Households with disabled or elderly members would require greater amounts. 
In Guyaba, $100 \%$ (26) of the participants used rainwater as their primary source of drinking water when it was available. Half of the participants had access to a polyethylene storage tank, the other half collected rainwater in spare containers. During the dry season, 16 participants $(61 \%)$ reported that a creek was their primary source of drinking water, 8 participants (31\%) reported using the river, and 2 participants reported that they depended on others to fetch water for them. Guyaba was the only community of the three to report any use of river water for drinking. Several of the women who reported using river water followed with explanatory comments. One woman who reported using the river said that she was impoverished for water; two others pointed out that although it gave them diarrhea, they did not know of any other options. The creek was not viewed much better, with four participants reporting problems with creek water such as bad water, stagnant water, bugs, and disease. Three other participants (two creek users and one river user) reported that they dug potholes in the banks adjacent to the water sources to create small seeps rather than fetching water from the source directly. The average household size in Guyaba was 4.6 people. Overall, the households counted were $32 \%$ women, $11 \%$ men, and $57 \%$ children.

\subsection{The Water Supply Systems - An Overview}

The results of the investigation for the three water systems showed significant variation in how well the water supply systems were functioning, as well as in how the communities perceived them. In the past five years since completion, all three communities had complete or partial breakdowns that lasted for at least a year. Abenaston fixed its water supply system with outside assistance. Kayapaati fixed its water supply systems through a donation made by a community member. The system in Guyaba is barely retaining functionality and has not been fixed. Neither Abenaston, Kayapaati, nor Guyaba used a protected water source for their water supply systems, which means that none of the water supply systems met the criteria for an improved water source under the MDG guidelines.

The costs for daily operation of the water system in Abenaston are $96 \%$ of the median cash income of women in Maroon communities in Suriname. The costs of running Abenaston's water supply system for one month out of the year totals $10 \%$ of the median cash income of women in Maroon communities. The costs for running the water system in Kayapaati were not available; the water pump was new and the community did not have enough experience running it yet to estimate its operation costs. However, the system is very similar to that of Abenaston. Guyaba operates using solar panels and does not have daily operating costs. None of the three communities paid the men who operated or maintained the systems, nor did they have any funds in reserve for maintenance or repairs to the water systems.

The water committee in Abenaston was still functioning, the water committee in Kayapaati had dissolved and its duties taken over by the women's organization, and the water committee in Guyaba had also dissolved, although a few community leaders occasionally assisted with maintenance duties. 


\subsubsection{Community Perceptions.}

This section presents an overview of community perceptions for all three communities and compares differences in responses by community and by gender. Explanations of how community perceptions related particularly to the performance of their respective water systems are discussed in more detail in the following sections. Table 4 provides a summary of the most common responses in the community perception surveys, collated by community and gender. (Appendix A provides the complete results from the surveys.) The wording used for the categories in the table was based on the wording of the responses given.

The most-mentioned response in the perception surveys in Abenaston was that operation and maintenance $(\mathrm{O} \& \mathrm{M})$ workers should be paid. This response always came up in discussions on willingness-to-pay. However, despite being the most common response in Abenaston, it was not a significant response in either Kayapaati or Guyaba. This is likely due to differences in the performance histories of the three systems. In Abenaston, the community clearly recognized the important role of O\&M workers to the success of the water system. This work is valued by the community. However, the community has not been able to collect enough money to pay for fuel costs, which take precedence over payments to O\&M men. (Although their work is valued, under social pressure the O\&M men work for free.) In contrast to the system in Abenaston, which has been running for a few years, in Kayapaati the system has only recently been restored to working order. Without anything to operate or maintain, there is no need to pay O\&M workers. In Guyaba, the need to pay O\&M workers was only mentioned by one man who had been helping with O\&M. He explained that without pay, he could not afford to spend his time doing free labor (this is also what the O\&M men in Abenaston reported). However, in Guyaba the efforts of the men volunteering time to O\&M have not been able to help poor system performance, which has deteriorated from bad to worse. Without any apparent value in the O\&M work, perhaps the community did not see it as necessary or important to the water system success.

Taking care of fuel costs was identified as a problem in both communities that had regular fuel costs (Abenaston and Kayapaati). This problem was also identified through technical evaluations of the water systems. Reported fuel costs were compared to incomes of Maroon women reported by an anthropologist. The yearly fuel costs for daily operation of the water system came to nearly $100 \%$ of the yearly median income of the women. Although reported fuel costs were not available for Kayapaati, the similarity of the two water systems makes it reasonable to assume that fuel costs for Kayapaati are comparable to that of Abenaston.

Both communities with regular fuel costs also had significant numbers of participants who described the strategy the community used to collect funds during the perception surveys. In Abenaston the water committee had begun timing payment collection with quarterly government pension payouts to the old (instead of their previous method of monthly collections). These pension payouts are distributed at a meeting house in the village center. As recipients exit with their cash, water committee members wait at the 
door to ask for a three-month advance payment of agreed upon water fees. This strategy is effective for two reasons. First, the old are the most likely to have difficulty with the labor and distances involved in fetching water, making them more vulnerable to water scarcity. Because of this vulnerability, the old place greater value on piped water systems and have a greater willingness-to-pay (WTP). Second, by timing fee collection to coincide with the time in which community members have cash in-hand, the water committee increases the chances that the fees will be paid immediately.

Kayapaati has adopted a different strategy. Instead of setting a standard water fee, the water committee recommends an amount but asks that people pay what they can. This adds a moral-obligation aspect to fee payment. The wealthy are encouraged to pay more and those who cannot pay are still encouraged to contribute. There is no data on whether or not this strategy increases fee revenues. Another aspect of this response in the surveys is that the majority of participants who mentioned this strategy were women. Women are more likely to be cash-poor, and it is possible that they placed greater value on the flexibility of this payment scheme, which reduces negative social connotations for nonpayment of the recommended amount.

In both Abenaston and Kayapaati, common responses regarding WTP were either that participants had no money or that they had no wage-work. These responses were often coupled together. Strangely, in Guyaba most participants gave vague or evasive responses about WTP. However, in Guyaba the water committee had never collected any fees from the community. The tone of the responses about WTP conveyed an attitude of unfamiliarity with the subject of fees. It may be quite simply that people in Guyaba did not have any context of fee collection (for any services, not just for water) with which to form opinions on WTP.

Moving from WTP to responsibility - Abenaston and Kayapaati had similar views on responsibility for the water systems. Approximately half of all participants for both communities assigned responsibility to the national government. However, in Guyaba, participants overwhelmingly assigned responsibility to village leaders. It should be noted that in practice in both Abenaston and Kayapaati, the community members had assumed all responsibilities themselves. It is possible that the participants assignation of responsibility to outside parties represented a desired, rather than an expected, state of affairs. It is unclear why Guyaba's responses did not correspond with the other communities. One possible explanation is that unlike the other communities the water project in Guyaba had been initiated and led by wealthy community leaders living in Paramaribo (as opposed to development workers working with interested community members). These leaders were still viewed as retaining responsibility for the project outcome. However, many participants (including 100\% of male participants) in Guyaba also assigned responsibility to project donors. Guyaba was also the only community of the three where the donors had provided additional assistance after completion of the system.

Problems mentioned with the water systems' performances fell into three categories: 1) the water flow was insufficient (the water is not enough), 2) the water is unreliable on a 
daily, weekly, or monthly basis (water flow is intermittent), and 3) the water does not meet local expectations for cleanliness in drinking water (the water is dirty). In Guyaba, $89 \%$ of participants also mentioned that water does not reach all taps. These responses indicate the types of technical problems that the water systems have.

All three communities had problems with insufficient or unreliable flows. Both of these problems can be traced back to the power source of the pump. In Abenaston and Kayapaati the cost of fuel to run the gasoline generators powering the pump is prohibitively expensive. They cannot afford to run the water system long enough during one day to provide sufficient supply nor can they afford to run the system daily. In Guyaba the water system is solar powered. Although there are no fuel costs, the solar panel arrays are not large enough to provide adequate power for the pumps to deliver sufficient supply. Water flows from the pump are almost negligible in cloudy weather, resulting in seasonal system operation.

The problem of dirty water in Kayapaati and Guyaba is due to the choice of the systems' water sources. Abenaston used a spring for the water source and few participants reported water-quality problems. On the other hand, the water source for Kayapaati is a creek which experiences drastic changes in quality between the wet and dry seasons (see Figure 10). Low, clear flows in the dry season are displaced by high, turbid flows in the wet season. In Guyaba the water source is a spring, nevertheless, the spring bed drains rainfall in the wet season, and the water quality is degraded by muddy runoff. One woman in Guyaba described the appearance of water from the system during the wet season as "tea made with milk".

Only Guyaba reported problems with dry taps. This is due to the pump flow being directly hooked up to the distribution network, bypassing the storage tank. Only one branch of the distribution network still receives pump flows.

In conclusion, the results of the community perception survey identified the main operational problems for each community, the strategies the communities used to deal with high fuel costs, and attitudes regarding O\&M duties and responsibilities. 
Table 4 Summary of the qualitative survey results on community perceptions.

\begin{tabular}{|c|c|c|c|c|}
\hline \multirow[b]{2}{*}{ Community } & \multirow[b]{2}{*}{ Most recurrent themes } & \multicolumn{3}{|c|}{ Number of Participants } \\
\hline & & Men & Women & Total \\
\hline \multirow{9}{*}{ Abenaston } & O\&M workers should be paid & $7(58 \%)$ & $10(83 \%)$ & $17(71 \%)$ \\
\hline & We do not have money & $9(75 \%)$ & $8(67 \%)$ & $17(71 \%)$ \\
\hline & Providing gasoline to run pump is a problem & $12(100 \%)$ & $5(42 \%)$ & $17(71 \%)$ \\
\hline & Mention that money is collected during pension payouts & $11(46 \%)$ & $4(17 \%)$ & $15(63 \%)$ \\
\hline & The national government should be responsible & $7(58 \%)$ & $5(42 \%)$ & $12(50 \%)$ \\
\hline & The water is not enough & $6(50 \%)$ & $6(50 \%)$ & $12(50 \%)$ \\
\hline & We do not have (wage) work & $2(17 \%)$ & $8(67 \%)^{*}$ & $10(42 \%)$ \\
\hline & Water flow is intermittent & $3(25 \%)$ & $1(8 \%)$ & $4(17 \%)$ \\
\hline & $N($ total $)$ & 12 & 12 & 24 \\
\hline \multirow{10}{*}{ Kayapaati } & Providing gasoline to run pump is a problem & $8(89 \%)$ & $7(64 \%)$ & $15(75 \%)$ \\
\hline & Water flow is intermittent & $7(78 \%)$ & $8(73 \%)$ & $15(75 \%)$ \\
\hline & We do not have money & $5(55 \%)$ & $6(55 \%)$ & $11(55 \%)$ \\
\hline & We do not have (wage) work & $5(55 \%)$ & $6(55 \%)$ & $11(55 \%)$ \\
\hline & The national government should be responsible & $7(78 \%)$ & $4(36 \%)$ & $11(55 \%)$ \\
\hline & The water is not enough & $6(67 \%)$ & $4(36 \%)$ & $10(50 \%)$ \\
\hline & The water is dirty & $3(33 \%)$ & $5(45 \%)$ & $8(40 \%)$ \\
\hline & We pay what we can & $1(11 \%)$ & $6(55 \%)$ & $7(35 \%)$ \\
\hline & Evaded questions about responsibility & $1(11 \%)$ & $6(55 \%)$ & $7(35 \%)$ \\
\hline & $N($ total $)$ & 9 & 11 & 20 \\
\hline \multirow{8}{*}{ Guyaba } & Water does not reach all taps & $7(88 \%)$ & $10(91 \%)$ & $17(89 \%)$ \\
\hline & Water flow is intermittent & $8(100 \%)$ & $7(64 \%)$ & $15(79 \%)$ \\
\hline & Village leaders (formal or informal) are responsible & $7(88 \%)$ & $8(73 \%)$ & $15(79 \%)$ \\
\hline & Evaded questions about willingness-to-pay & $8(100 \%)$ & $5(45 \%)$ & $13(68 \%)$ \\
\hline & The water is dirty & $7(88 \%)$ & $5(45 \%)$ & $12(63 \%)$ \\
\hline & The project donors should be responsible & $8(100 \%)$ & $3(27 \%)$ & $11(58 \%)$ \\
\hline & The water is not enough & $4(50 \%)$ & $5(45 \%)$ & $9(47 \%)$ \\
\hline & $N($ total $)$ & 8 & 11 & 19 \\
\hline
\end{tabular}

* Cells highlighted with bold text indicate responses that were made predominantly by either men or women 


\subsection{Abenaston}

Abenaston is a small Saramaka community of 300 people on the Upper Suriname River (Figure 6). The water system was installed in 2005 is still operating today, although it had an extensive breakdown that lasted for approximately two years. Under optimal conditions it is capable of producing 7200 gallons per day (24 gallons per person). The system supplies piped water to 40 communal taps in the community by gravity from an elevated storage tank. Water is pumped to the tank from a nearby spring using a gasolinepowered generator. This section describes the current status of the water system, its history, a technical overview, the community perceptions of the water system, and the results of the sustainability audit of the water system project.

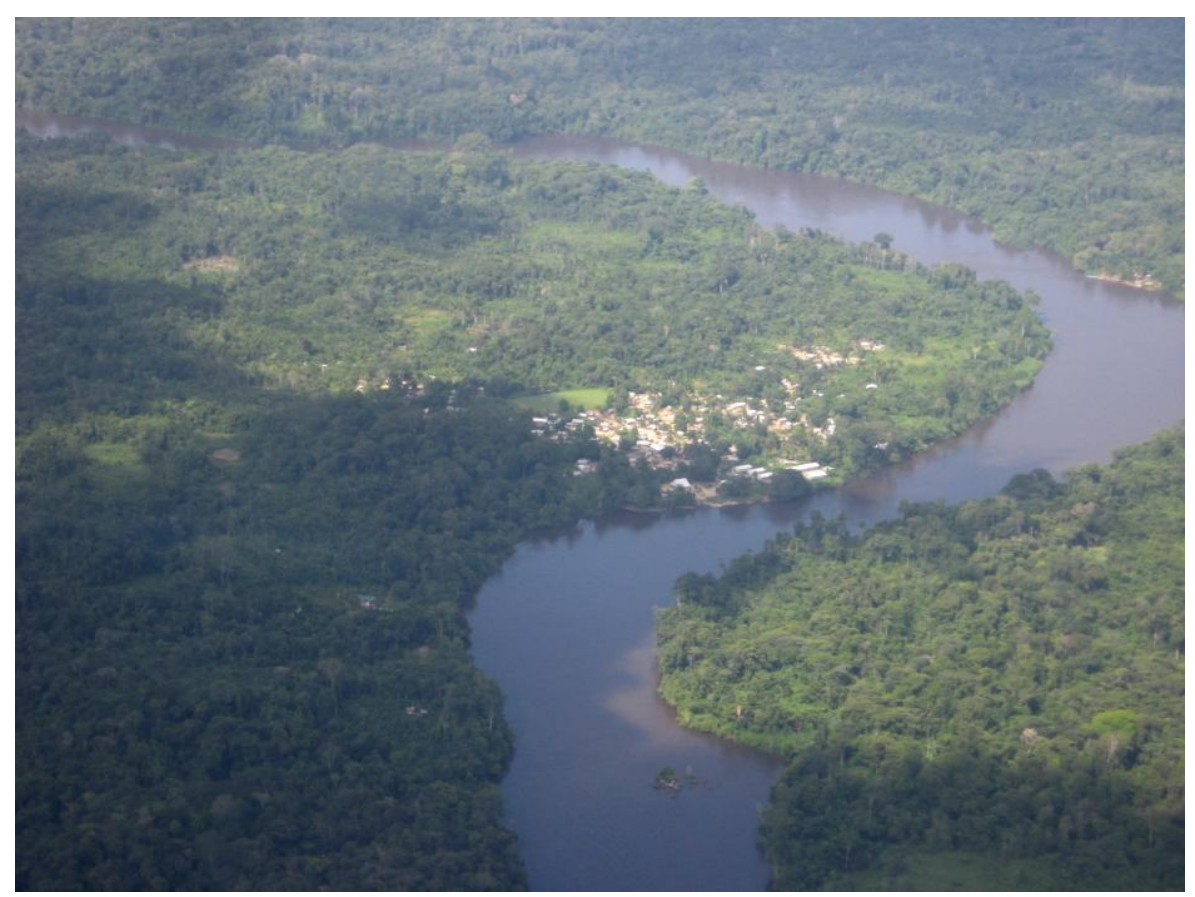

Figure 6. Abenaston as seen from the air. The river flows from bottom to top.

\subsubsection{The Water System Today}

Today's water supply system in Abenaston does not qualify as an improved water source under the World Health Organization guidelines (WHO 2011) because the water source is unprotected. This system fails to meet the criteria to count as providing clean drinking water under the United Nations' Millennium Development Goals (MDGs), which Rotary Club International uses to help tally their efforts in improving water and sanitation. The original construction lasted for less than a year. The water supply system, which was designed to run daily, only runs occasionally. The community has no funds in reserve for future breakdowns or larger maintenance issues. 
However, the water system, five years after construction, is still operational and technically sufficient. The community searched for and found outside assistance to rebuild the system after the pump and intake broke, and the water committee is still collecting funds and doing basic maintenance. Despite setbacks, the community has not abandoned the project - the community runs the water system during times of greater water scarcity. Members of the community, male and female, are aware of issues facing their water system and what they have done as a community to address them, indicating a sense of ownership.

\subsubsection{The History of the Water System}

The process of acquiring a water system began in 2000 with a participatory community assessment done with the community by a female Peace Corps Volunteer (PCV). The community identified additional school classrooms and a water supply system as their first priorities. The school classrooms were built but funding for the water supply system was not available at that time. In 2004, two new female PCVs, working with a female counterpart from the community, found funding for the water supply system through the Rotary Club - Paramaribo. The water committee formed in 2000 was re-activated. The community contributed $15-25 \%$ of the capital costs of the water system in labor and materials. Some, but not all, tests of the quality of the water source showed fecal contamination. The addition of a slow-sand filter to the water supply design to address the possibility of fecal contamination caused some tension between the donors and the community - the community saw it as unnecessary and requiring additional labor and materials. Although construction went smoothly with good community participation, the head of the water committee refused to sign the official ownership documents at the handover ceremony until pressured by community leaders.

The water supply system worked for three to six months before breaking down. The cause could not be determined in this investigation. The water system was broken for about two years before another donor replaced the system intake and pump (see Figure 7). The water committee began collecting funds to run the system. After attempting monthly door-to-door collection of water fees, the water committee switched to collecting funds quarterly to coincide with the government's distribution of social security payments to the elderly - they stand outside the building where funds are being distributed and ask for water payments as recipients exit. 




Figure 7. The intake for the water system at the time of evaluation, May 2010. The weir can be seen along with the gravel bed covering the intake in the center of the photo. The pyramidal structure in the left of the photo is the original slow sand filter.

\subsubsection{Technical Overview}

The water supply system in Abenaston is technically adequate for providing minimum levels of water supply to the community. The pump and generator used in the system are capable of filling the water storage tanks (see Figure 8 for the pump performance curve and system head curve). However, the water source used for the system is unprotected and unfiltered, therefore the water supply system does not qualify as an improved water source under the MDG guidelines (WHO 2011). The adequacy of the system in supplying sufficient quantity has been compromised since one of the three polyethylene water storage tanks has been decoupled from the system. The specifications of the water system are given in Table 5 below. 
Table 5 The specifications for the water supply system in Abenaston, as observed at the time of the evaluation in May 2010.

\begin{tabular}{ll}
\hline Abenaston Water System Specifications & \\
\hline water source: & Soekoenale Spring \\
distance to water tank: & 500 feet \\
depth of intake from pump: & 5 feet \\
height of tank: & 20 feet \\
piping size: & 1.25 inches \\
type of piping: & PVC \\
tank capacity: & 1800 gallons \\
\# of taps in the community: & 40 \\
type of pump: & shallow jet pump \\
make and model: & Flotec FP4022, $3 / 4 \mathrm{hp}$ \\
power source: & gasoline generator \\
population of community: & 300 people \\
Average volume of water per person: & $\mathbf{2 3 ~ l i t e r s / d a y ~}$ \\
cost of gasoline to run pump (one tank of gas for & \\
generator): & $\$ 12.72$ per day \\
cost of gasoline for one month & $\$ 381.82$ per month \\
cost of gasoline per year & $\$ 4,645.45$ per year \\
cost of daily operation per (adult) community & \\
member & $\$ 38.71$ per year \\
\hline
\end{tabular}

Note: one of the 600 gallon tanks has been disconnected, reducing tank capacity to 1200 gallons, and water per person to 15 liters/day

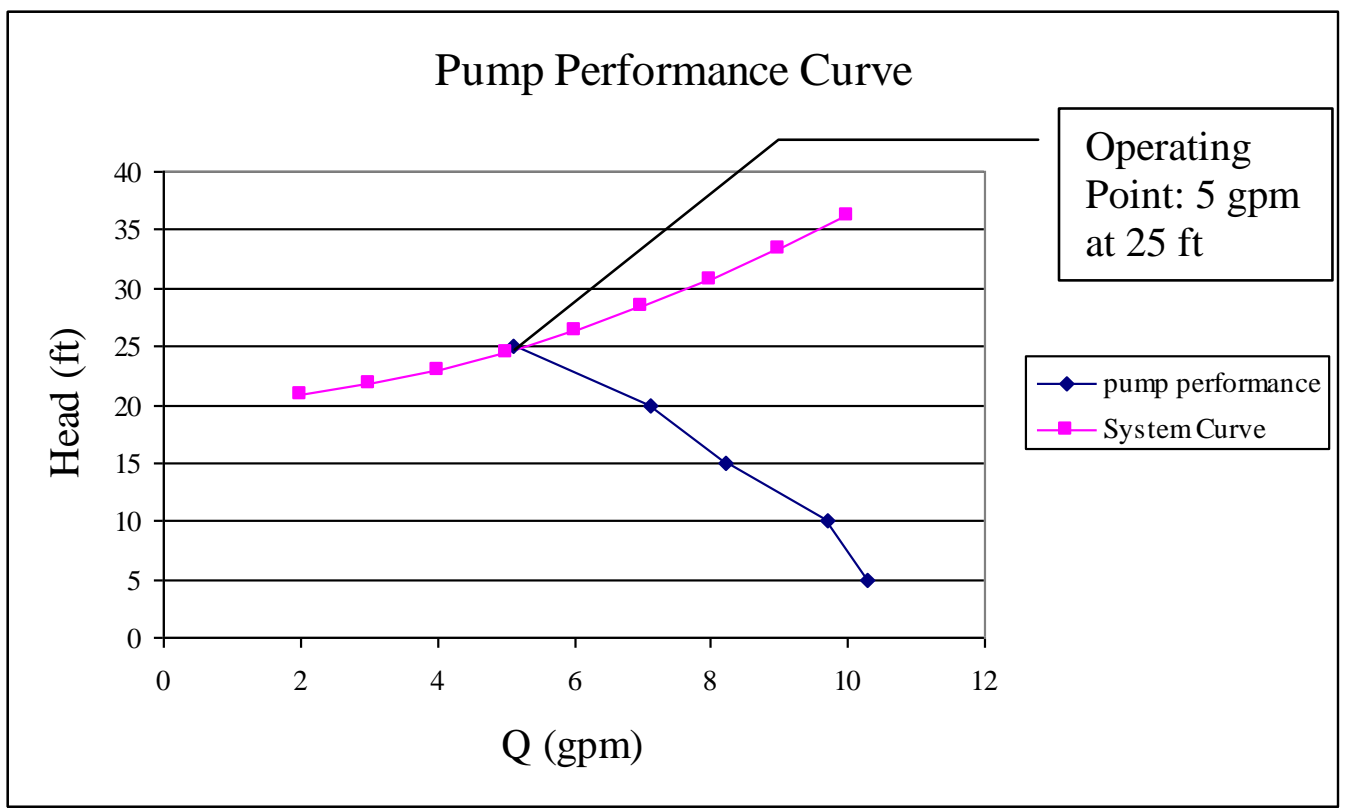

Figure 8. The pump performance curve and system curve show that the pump is capable of flows approximately of 5 gallons per minute to the water storage tanks. 


\subsubsection{Community Perceptions}

As can be seen in Table 5, the major themes that emerged from the qualitative interviews in Abenaston are economic. Based on the responses from the community, the water system appears to economically infeasible. The costs of the running the water supply system were identified by community members as falling into two categories: paying the operation and maintenance men and buying fuel to run the pump. The participants who responded that the operation and maintenance men should be paid explained that since the men do not get paid, if they have a chance for paid work they will not run the water system. Rather than criticizing the men for this, the community expressed gratitude that they ran the water system at all. The community had not addressed this issue by collecting extra fees because the amount of fees that they managed to collect did not even cover the more inflexible costs of fuel.

The few number of responses complaining about intermittent water supply indicates that the community is usually able to operate the system in times of water scarcity (such as the dry season). The lack of responses about poor system performance or issues with water quality indicates that the water supply system is satisfactory when it operates. Many respondents indicated that they believed that responsibility for the water supply system should lie with the national government, which is unsurprising given the government's precedent of supplying funds for payment of operation and maintenance men in nearby communities. Other respondents were more inclusive in assigning responsibility - one man from Abenaston replied: "we want help from the people who will help us."

\subsubsection{Sustainability Assessment - Abenaston}

The details for scoring the sustainability factors are provided in Appendix D. The results were compiled into final scores and are listed in Table 6 . The scores for each element (row, column) can be as high as 4 , so a row or column can total as much as 20 to represent a maximum potential for sustainability. For the Abenaston community, the score of 43 out of 100 is probably known to a \pm 1 confidence interval for the majority of the Sustainability Factors. By accounting for elements that already have their highest or lowest possible score, the possible range of scores for this audit is 24 to 64 out of 100. 
Table 6 The results of the sustainability assessment matrix (McConville and Mihelcic 2007) for Abenaston.

\begin{tabular}{|c|c|c|c|c|c|c|}
\hline \multicolumn{7}{|c|}{ Sustainability Factor } \\
\hline Life Stage & $\begin{array}{l}\text { Socio- } \\
\text { Cultural } \\
\text { Respect }\end{array}$ & $\begin{array}{l}\text { Community } \\
\text { Participation }\end{array}$ & $\begin{array}{l}\text { Political } \\
\text { Cohesion }\end{array}$ & $\begin{array}{l}\text { Economic } \\
\text { Sustainability }\end{array}$ & $\begin{array}{l}\text { Environmental } \\
\text { Sustainability }\end{array}$ & Total \\
\hline $\begin{array}{l}\text { Needs } \\
\text { Assessment }\end{array}$ & 4 & $\mathrm{C}_{1}$ &  & 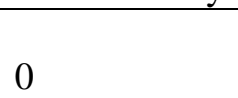 & $e^{2}$ & 12 \\
\hline $\begin{array}{l}\text { Conceptual } \\
\text { Designs and } \\
\text { Feasibility }\end{array}$ & 2 & 3 & 4 & 1 & 3 & 12 \\
\hline $\begin{array}{l}\text { Design and } \\
\text { Action } \\
\text { Planning }\end{array}$ & 4 & 0 & 0 & 2 & 0 & 6 \\
\hline $\begin{array}{l}\text { Implemen- } \\
\text { tation }\end{array}$ & 3 & 1 & 2 & 1 & 1 & 8 \\
\hline $\begin{array}{l}\text { Operation and } \\
\text { Maintenance }\end{array}$ & 0 & 3 & 2 & 0 & 0 & 5 \\
\hline Total & 13 & 11 & 9 & 4 & 6 & 43 \\
\hline
\end{tabular}

Socio-cultural respect: The water project in Abenaston scored best in the area of sociocultural respect. This factor, which incorporates an understanding of local rhythms and the availability of resources in the community, is one of the most critical, not only for long-term success but simply to get the project done. One of the reasons that the project scored relatively well in this area has to do with the relationship between the development workers and the community. This project was conceived and coordinated through Peace Corps volunteers who had committed to living in the community for two years. In addition to placing the volunteers in an optimum position for communicating with their community, they speak the local language and live and dress in much the same manner that their neighbors do. In this project, all of the volunteers involved with the project were women, which would have enabled them to particularly understand and address women's concerns. A female counterpart in the community during the design and action planning and implementation stages facilitated participation from women even when the community's decision makers and a majority of their water committee members were men. The project's weaknesses in this area lay in not recognizing the bias of both the community and donors towards one type of technology - gravity fed water systems and in the final life stage of the project, performing no evaluation of how the finished water system was impacting the community.

Community Participation: The water project also scored well in community participation, especially in the beginning and final stages of the project. At the start of the project the community was extensively involved. The original project was formulated in collaboration with community members and Peace Corps volunteers, and even written in Saramaka (an ambitious undertaking for an unwritten language) and then later translated into Dutch to ensure that all parties were clear on what the project entailed. A water committee was in place before the donors funded the project, and they helped organize 
labor and the rest of the community contribution. The community was likewise involved in the operation and maintenance stage - with a minimum of involvement from the donors after completion of the water system, the community was then making all decisions regarding operation and maintenance. The weakest scores for this factor are in the design and action planning and implementation stages. This was due to poor interaction between the building contractor and the community. The building contractor employed an authoritarian approach to the construction. As the main contact between the donors and the community during this time period, he shared no details of the budget or of spending and did not involve community members in scheduling or organizing work. This lack of transparency did not facilitate empowerment of the community to adequately maintain or fix the water system, and may have contributed to the rapid breakdown of the water system after construction.

Political Cohesion: The water project scored more poorly in the area of political cohesion. Efforts that would have improved this score include consulting with organizations that had done similar projects and involving regional and national government throughout the project and not just at the ceremony to hand over ownership of the water system to the community. Some of the difficulties in aligning the project with the country's priorities are due to Suriname maintaining a mostly hands-off approach to dealing with water and sanitation in the remote interior of the country. The few efforts the national government has made in the region are haphazard and include only a few communities. Despite this, community members in Abenaston recognize that the government pays maintenance workers in other communities nearby, and even today continue to hope that the government will someday begin paying their maintenance men. One aspect that the project excelled in, however, was in coordinating efforts of several different organizations to work on the project. The community's contributions were coordinated by Rotary Club - Paramaribo with Peace Corps volunteers, several outside donors, and the building contractor.

Economic Sustainability: The area of economic sustainability was the project's weakest. Although the project successfully coordinated the economic contributions during the water system construction, little energy was given to ensuring that the community had the resources and capacity to successfully take ownership of it after completion. In the needs assessment there was no attempt at ascertaining willingness (or ability) to pay. Nor was there an assessment of the economic feasibility of the water system in the long-term based on projected costs. After the project began, the budget and spending were not shared with the community or partner organizations and there was no budget review at the end of the project. There was no evaluation after completion if true operation and maintenance costs were manageable, or if the financing system set up was adequate to provide for these costs. It is true that an official willingness-to-pay survey using methods such as contingent valuation would be impossible in such a small community. However, several similar water projects in the region could have been used as a data source to give better estimates. In the community perception interviews, community members were highly aware of this weakness in their project and economic issues were the most common themes to arise out of the interviews. This weakness has also been the biggest 
obstacle in all the challenges the water system has faced, from the community being unable to fund repairs on their own, to being unable to run the system regularly.

Environmental Sustainability: Despite scoring poorly in the area of environmental sustainability, the effects of this low score did not correspond to problems in the water supply system operation. This is due to the overall low environmental impact of the project. The spring used as the water source still has a section of unobstructed flow, many of the resources needed for the project were obtained locally, and the introduction of the water system created no meaningful environmental effects. Nevertheless, no particular effort was made to recognize possible harmful effects and there was no coupling of the water supply system construction with waste management training or environmental education.

\subsection{Kayapaati}

Kayapaati is a small Saramaka community of 400 people on the Upper Suriname River (Figure 9), approximately two kilometers upstream of Abenaston. The water system, which was completed in 2005, suffered from an extensive breakdown of the pump for several years. The community has recently acquired a new pump which had been in operation for only two months during the time of the investigation. Under optimal conditions it is capable of producing over 11,000 gallons per day (about 30 gallons per person). The system supplies piped water to 40 communal taps in the community by gravity from an elevated storage tank. Water is pumped to the tank from a nearby creek using a combination pump and gasoline generator. This section describes the current status of the water system, its history, a technical overview, the community perceptions of the water system, and the results of the sustainability audit of the water system project.

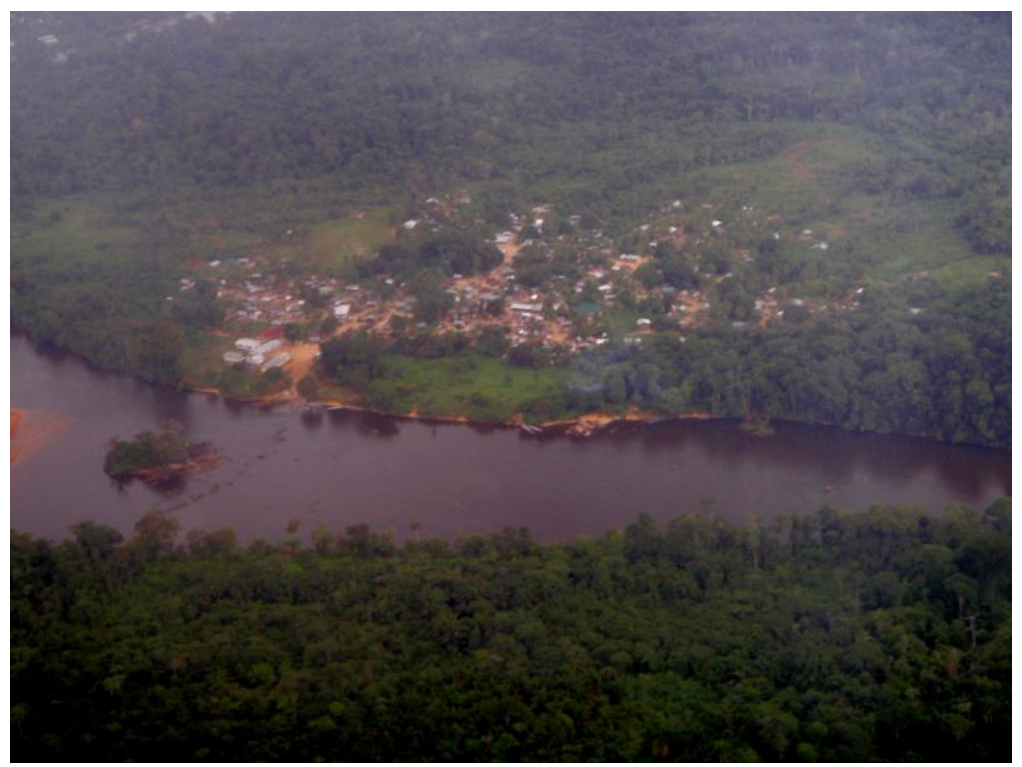

Figure 9. Kayapaati from the air. The river flows from right to left. The creek which serves as the water source for the community discharges to the left and outside of the picture frame, and the creek itself is not visible due to the vegetation. 


\subsubsection{The Water System Today}

The water supply system in Kayapaati does not qualify as an improved water source under the World Health Organization guidelines (WHO 2011), because the water source is unprotected. Like Abaneston's, this system fails to meet the criteria to count as providing clean drinking water under the UN MDGs.

The original construction broke down after only a year or two in operation. The water supply system, which was designed to run daily, is only run occasionally. The community has no funds in reserve for future breakdowns or for larger maintenance issues. The operation of the water system has become a source of conflict in the community, provoking tensions between traditional and informal leadership.

Despite the fragile conditions, the water system, five years after construction, is still operational and technically sufficient. The community was able to replace the broken pump on its own, and community members organized themselves to revitalize the water system. The women of the community have stepped up to take the lead role in managing the community's water resources in the same way that they manage their own households' water.

\subsubsection{The History of the water system}

The process of developing a water supply system began around 2002, initiated by a married couple who were Peace Corps volunteers living in the community. The community's women's organization was tapped to be the counterpart for the project. The Peace Corps volunteers left and passed the project on to a new male Peace Corps volunteer who began working on it with a male community counterpart who was also the son of the traditional head authority in the community. In 2004, funding was acquired through the Rotary Club - Paramaribo. Community participation was low, and the community contribution of $15-25 \%$ of the capital costs was acquired through social coercion to provide the labor and materials. There is no record of water quality testing being done on the water source used for the system. The building contractor constructing the water system was viewed suspiciously by the community. Although no community members were initially interested in being on the water committee, after the successful construction of the water system a water committee was formed.

The water system operated for a year or two and then broke down. The water committee dissolved. It remained broken until early in 2010 when the women's organization convinced a community member who had done well working in the illegal gold mines north of the region to buy a new pump.

The women's organization stepped in to serve as the water committee. The traditional head authority in the village was not involved in the re-activation of the water supply 
system and was quite agitated about this at the time of the investigation in May 2010. The water system had not yet been run frequently enough to estimate running costs or to establish management procedures for collecting funds.
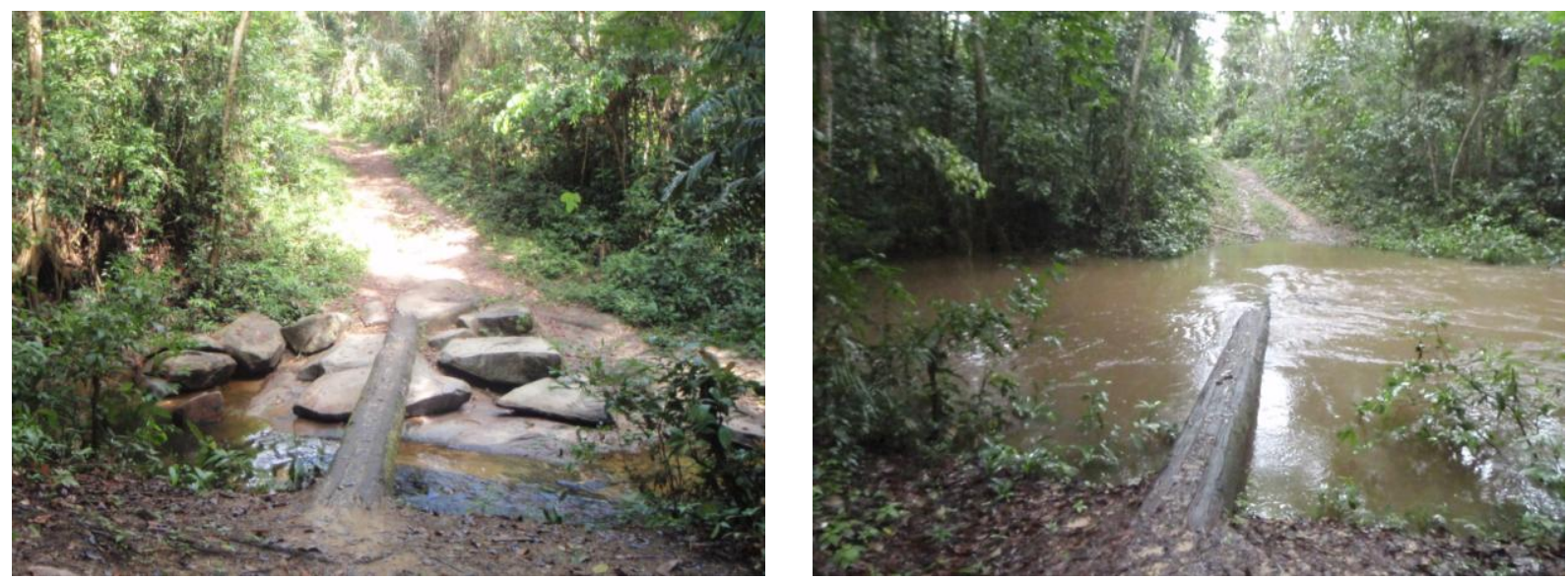

Figure 10. Kayapaati Creek in the dry season (left) and the rainy season (right). In the right photo the water is waist deep if standing on the submerged section of the log.

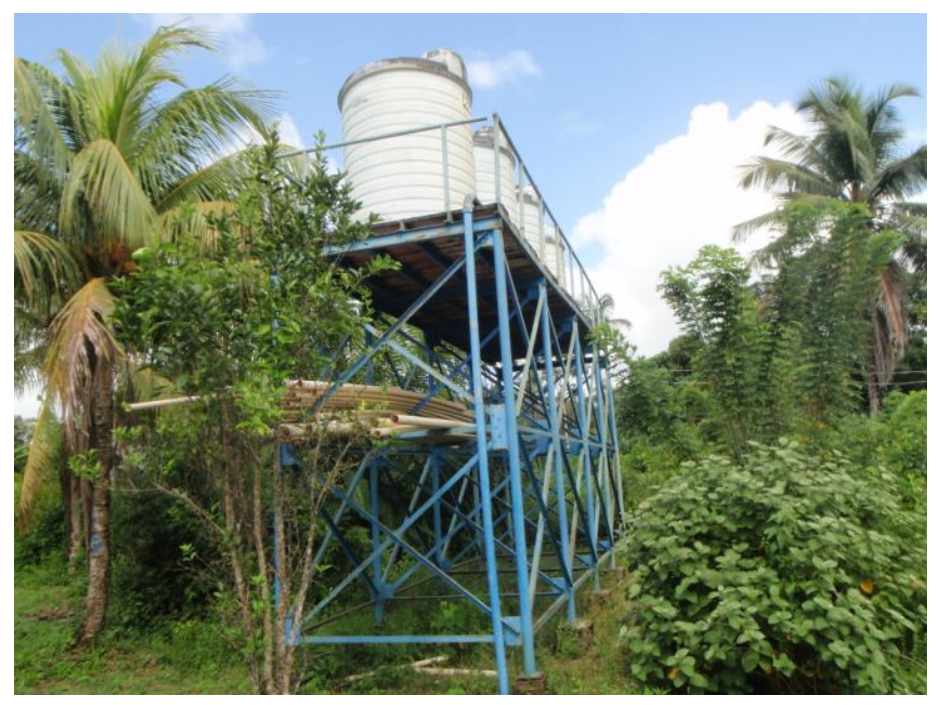

Figure 11. The water tower in Kayapaati and its polyethylene storage tanks.

\subsubsection{Technical Overview}

The water supply system in Kayapaati is technically adequate for providing minimum levels of water supply to the community. The pump and generator used in the system are capable of filling the water storage tanks (see Figure 12 for the pump performance curve and system head curve). However, the water source used for the system is unprotected and unfiltered, therefore the water supply system does not qualify as an improved water source under the MDG guidelines (WHO 2011). The specifications of the water system are given in Table 7 below. 
Table 7 The specifications for Kayapaati's water supply system as observed at the time of the evaluation in May 2010.



Cost estimates from the community were not yet available for the new pump

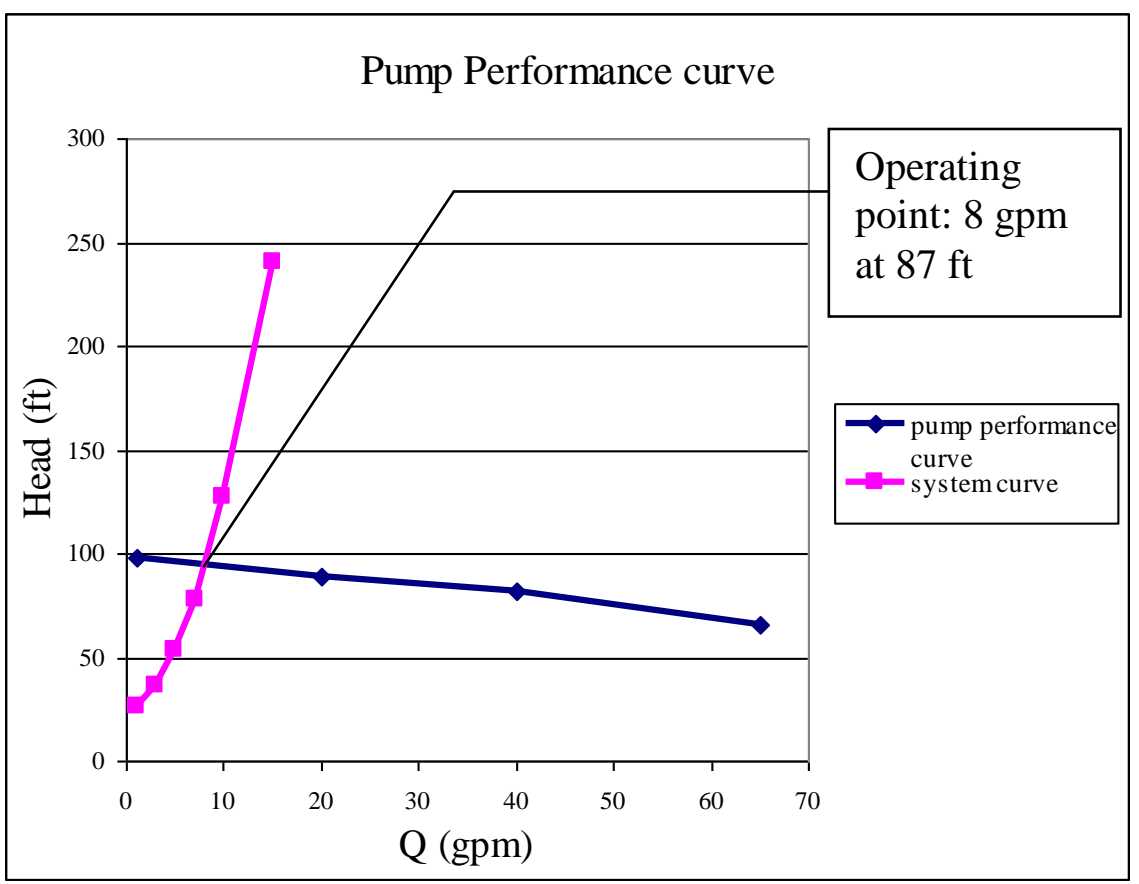

Figure 12. The pump performance curve and system curve show that the pump is capable of flows approximately of 8 gallons per minute to the water storage tanks. 


\subsubsection{Community Perceptions}

As can be seen in Table 7, the primary themes generated in the qualitative interviews with community members were economic. Based on the responses from the community, the water supply system appears to be economically infeasible. Although common responses included both "we don't have money" and "we don't have work", there were no responses claiming poverty. The high number of replies that water flow was intermittent indicates that water supply has not been available during times of water scarcity. Since the water system was only restored to operating condition a few months before the evaluation, it is not surprising that the system was still viewed as failing to meet fundamental water needs. Most male participants indicated that they believed that responsibility for the water supply system should lie with the national government, which corresponds with the national government's precedent of supplying funds for payment of operation and maintenance men in nearby communities. However, in this community, where women have taken over management of the water supply system without being sanctioned by traditional (male) community authorities, over half the female participants evaded answering questions about responsibility entirely. There was also greater suspicion in this community towards the researcher. For example, in one interview a female participant openly admonished her companion for voicing grievances with the water system, adding: "we don't know this woman!".

\subsubsection{Sustainability assessment - Kayapaati}

The details for scoring the sustainability factors are provided in Appendix D. The results were compiled into final scores and are listed in Table 8. The scores for each element (row, column) can be as high as 4 , so a row or column can total as much as 20 to represent a maximum potential for sustainability. For the community of Kayapaati, the score of 29 out of 100 is known to a \pm 1 level of confidence. By accounting for elements that already have their highest or lowest possible score, the possible range of scores for this audit is 13 to 53 out of 100 . 
Table 8 The results of the sustainability assessment matrix (McConville and Mihelcic 2007) for Kayapaati.

\begin{tabular}{|c|c|c|c|c|c|c|}
\hline & sustainability & actor & & & & \\
\hline life stage & $\begin{array}{l}\text { socio-cultural } \\
\text { respect }\end{array}$ & $\begin{array}{l}\text { community } \\
\text { participation }\end{array}$ & $\begin{array}{l}\text { political } \\
\text { cohesion }\end{array}$ & $\begin{array}{l}\text { economic } \\
\text { sustainability }\end{array}$ & $\begin{array}{l}\text { environmental } \\
\text { sustainability }\end{array}$ & total \\
\hline $\begin{array}{l}\text { needs } \\
\text { assessment }\end{array}$ & 3 & 1 & 0 & 1 & 2 & 7 \\
\hline $\begin{array}{ll}\text { conceptual } \\
\text { designs } \\
\text { feasibility }\end{array}$ & 1 & 1 & 4 & 0 & 3 & 9 \\
\hline $\begin{array}{l}\text { design and } \\
\text { action planning }\end{array}$ & 2 & 0 & 0 & 2 & 0 & 4 \\
\hline implementation & 3 & 1 & 2 & 1 & 1 & 8 \\
\hline $\begin{array}{l}\text { operation and } \\
\text { maintenance }\end{array}$ & 0 & 0 & 2 & 0 & 0 & 2 \\
\hline total & 9 & 3 & 8 & 4 & 6 & 29 \\
\hline
\end{tabular}

Socio-cultural respect: Similar to the results of Abenaston, the project scored relatively well in the area of cultural respect. One notable lack in this area was participation from women. The women's organization had been involved with the project at the beginning in the needs assessment stage but was excluded from the decision-making processes during the rest of the project. For this reason, Kayapaati scored lower than Abenaston in the area of socio-cultural respect.

Community Participation: In contrast with the water project in Abenaston, there were low levels of community participation in all stages of the project life cycle. Low levels of community participation were first exhibited when the community could not put together a water committee. In the intermediate stages, low levels of community participation forced leaders involved with the project to socially coerce the community into completing their portion of the community contribution. In the operation and maintenance stage, the water committee still had little function and the community counterpart and a Peace Corps volunteer were still doing all the fund collection. Recently there has been an increase in community participation from the involvement of the women's organization and men associated with it. The manner in which the women's organization took over management of the water system has created tensions between the organization and the village captain (the traditional authority figure in the community). Tensions between leaders in the community may erode community support for the water system if the system gets turned into a political issue.

Political Cohesion: This project was administered in the same manner as Abenaston. See Abenaston's sustainability audit for details.

Economic Sustainability: This project was administered in the same manner as Abenaston. See Abenaston's sustainability audit for details. 
Environmental Sustainability: This project was administered in the same manner as Abenaston. One main difference is that the water source is subject to seasonal variation. The flow of the creek is significantly lower in the dry season (Figure 10), and it is foreseeable that it might go dry in a very dry year. Monitoring the seasonal flow in the creek would have ensured that the water source chosen was reliable.

\subsection{Guyaba}

Guyaba is the largest Saramaka community on the Upper Suriname River, approximately 16-km upriver from Abenaston, with 2500 people. Spanning only a square kilometer of area, the community is densely populated and faces challenges more similar to peri-urban communities rather than rural ones. The small creeks on either side of the community are increasingly contaminated from runoff, and poor drainage in the community has created a swamp in its center. None of the creeks close to the community are reliable in the dry season. The water system, which was completed in 2005 , has performed poorly from the time of its original construction. Under optimal conditions it is capable of producing 27,000 gallons per day (about 10 gallons per person). The system supplies piped water to 48 communal taps in the community by gravity from an elevated storage tank. Water is pumped to the tank from a nearby spring using two solar-powered pumps. This section describes the current status of the water system, its history, a technical overview, the community perceptions of the water system, and the results of the sustainability audit of the water system project.

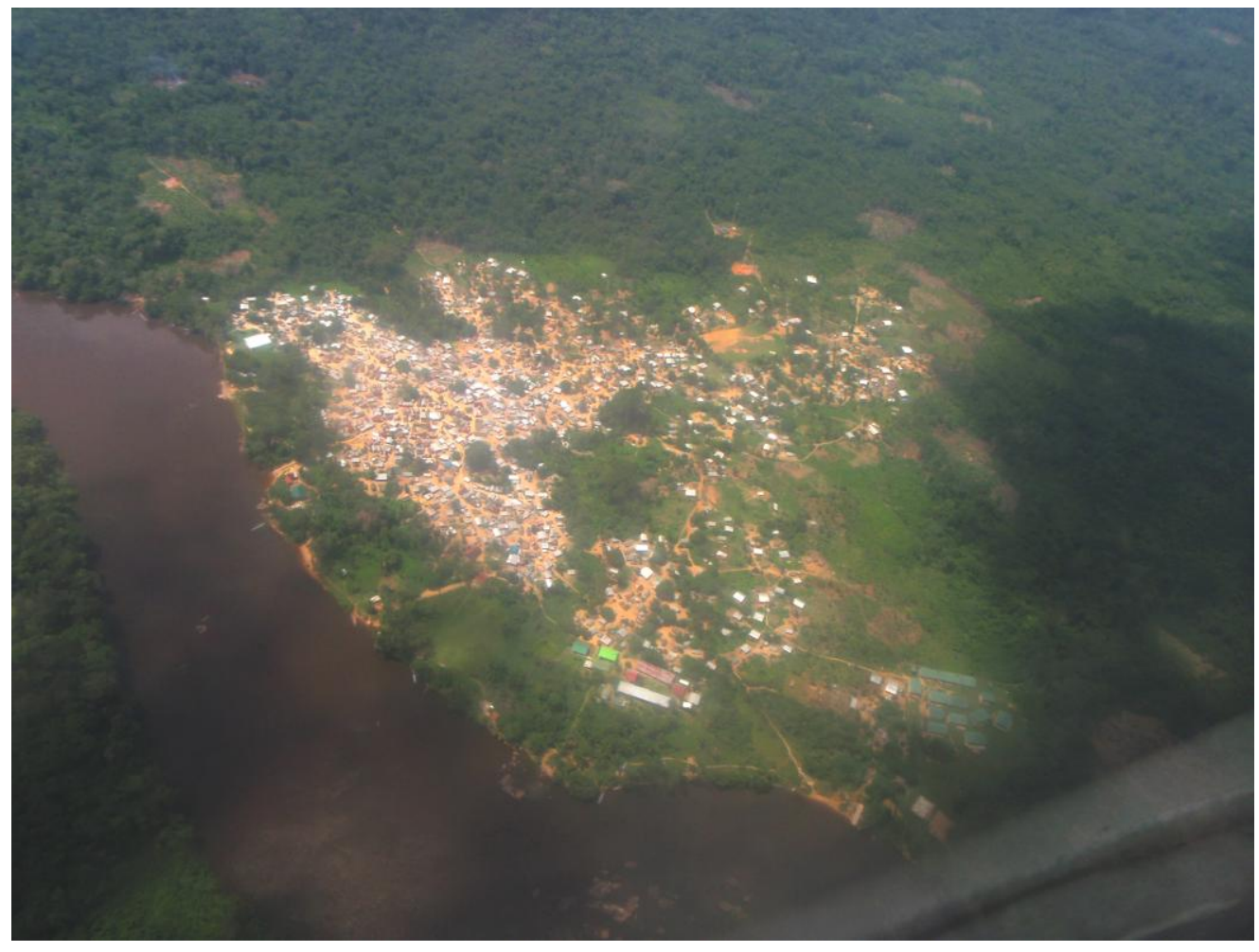

Figure 13. Guyaba from the air. River is flowing from left to bottom right. 


\subsubsection{The Water System Today}

The water system in Guyaba is technically insufficient. Five years after completion, only one of the two pumps works consistently and neither receives sufficient power to operate adequately. The community has re-routed the pump flow directly into the distribution network, which will deteriorate the distribution network and potentially harm the pumps. The majority of the taps have gone completely dry. Additionally, the water system in Guyaba does not qualify as an improved water source under World Health Organization guidelines (WHO 2011) because the source is unprotected. The water committee has dissolved. There is little to no participation in water system issues from women, despite being the primary water users.

\subsubsection{History of the Water System}

Guyaba was the only community in this investigation to report drinking river water, which is known to cause diarrhea. Some people who resort to drinking river water dig potholes in the river bank to create seeps, which provide some filtration. Community leaders requested assistance acquiring a water supply system from the Foundation for the Development of Guyaba and its Surroundings (STOGO), which is a local NGO made up of people whose families are from Guyaba. STOGO found funding for the project through Rotary Club - Paramaribo. The system in Guyaba employed solar panels as the power source for the pumps instead of using a gasoline-powered generator. The water source chosen for the system was a small spring one kilometer from the community that was not traditionally used as a water source. There is no record of the source being tested for water quality. Construction of the water supply system went smoothly, with good community participation.

At completion of the water supply system in 2005, it did not perform adequately; not enough water was being pumped to the water tank to supply the community. Although Rotary Club - Paramaribo typically exits the community after completion of the water supply system, they had additional projects in Guyaba. Petitions for more assistance from the community led to the Rotary Club - Paramaribo replacing the pumps twice to try to achieve the design flows. STOGO was displeased with the results of the water project and informed community leaders that they should not collect any funds for operation and maintenance of the water system until it was operating at the level promised during the design phase: daily water flow at all times of day. This level of operation was never achieved. The water committee has gradually dissolved. The pump flows have been rerouted by the community around the water storage tank to pump water directly into the distribution network of communal taps. Rather than improving water flows, this has caused the majority of the taps to go permanently dry.

In addition to inadequate operation of the water system, community leaders believed that the donors or building contractor had stolen funds from the project budget and asked for a 
greater community contribution to make up the difference. Although the initial project budget planned for the community to contribute $16 \%$ of the total costs, the community leaders believed that they had been asked to contribute 60\% (in Dutch, as in English, sixteen and sixty sound very similar when spoken). After being informed by a visiting donor that they should not have been required to contribute more than $25 \%$ of the total project costs, the community leaders of Guyaba concluded that either the Rotary Club Paramaribo or the building contractor had stolen $35 \%$ of the project funds. This was their belief at the time of the evaluation in 2010 .

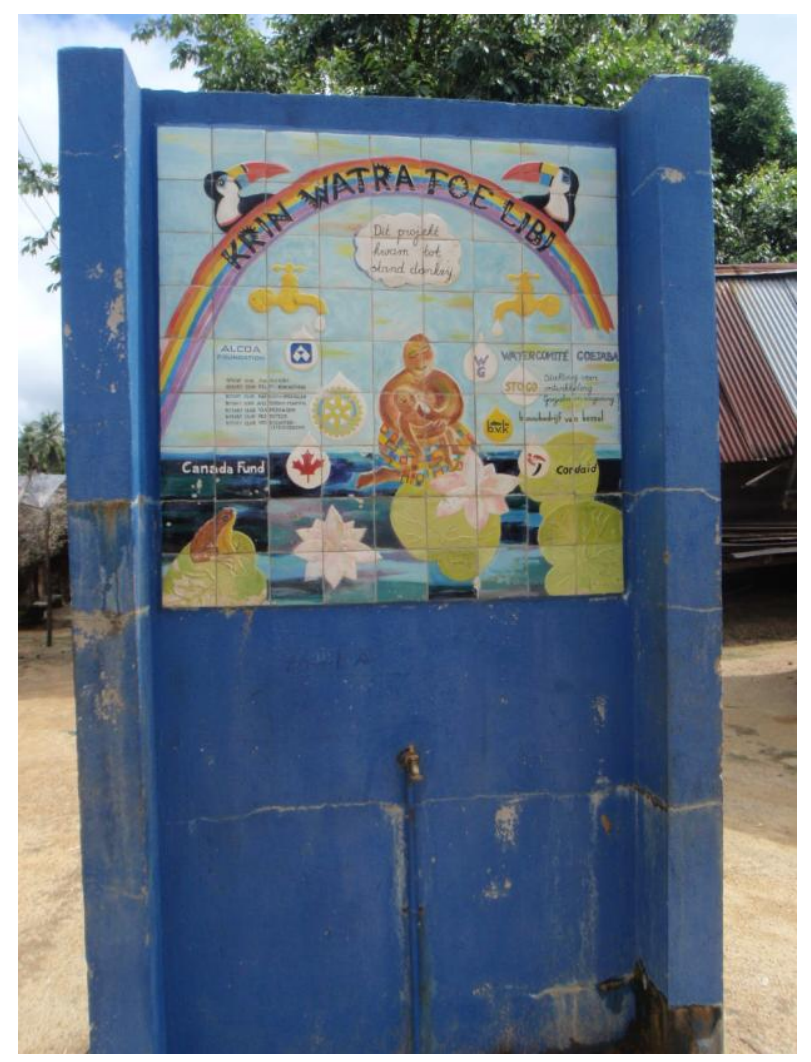

Figure 14. The water project donor monument board. It says "Clean Water For Life" across the top. The faucet below is dry.

\subsubsection{Technical Overview - Guyaba}

The water supply system in Guyaba is technically inadequate for providing minimum levels of water supply to the community. The pump and generator used in the system are incapable of filling the water storage tanks or providing design flows. Additionally, the water source used for the system is unprotected and unfiltered, therefore the water supply system does not qualify as an improved water source under the MDG guidelines (WHO 2011). The specifications of the water system are given in Table 9 below. 
Table 9 The specifications of the water supply system in Guyaba as observed at the time of evaluation in July 2010.

\begin{tabular}{ll} 
Guyaba water system specifications & \\
\hline source: & Spring \\
distance to water tank: & 3553 feet \\
depth of intake from pump: & 1 foot \\
height of tank: & 31.5 feet \\
piping size: & 4 inches \\
type of piping: & PVC, Steel \\
tank capacity: & $80 \mathrm{~m}^{3}$ \\
\# of taps: & 48 \\
\# of pumps & 2 \\
type of pump: & Centrifugal \\
make and model: & Grundfos SQFlex \\
power source: & solar panels \\
size of solar panel & 125 Watts \\
area of solar panel & $1 \mathrm{~m}^{2}$ \\
\# of solar panels & 12 \\
population of community: & 2500 people \\
\hline
\end{tabular}

The volume of water pumped by a solar-powered system is as variable as the weather. Pump performance has been calculated using solar radiation values and solar panel outputs for sunny and partly cloudy days.

First, the amount of solar radiation received in Suriname was calculated using the MIDC SOLPOS spreadsheet created by the National Renewal Energy Laboratory operated by the U.S Department of Energy. This spreadsheet can be found online at http://www.nrel.gov/midc/solpos/solpos.html. The amount of extraterrestrial global irradiance received on a tilted surface $\left(\mathrm{W} / \mathrm{m}^{2}\right)$ was calculated for the dimmest day of the year, winter solstice, for optimally oriented panels and a 20 degree tilt (the precise degree of tilt of the solar panel arrays could not be measured due to the height of the arrays).

Information on the brand and type of solar panel used in Guyaba was unavailable, but the design documents stated that the solar panels used would be $125 \mathrm{~W}$. The specifications for Sharp Electronics 123 Watt solar panels (model ND-123UJF) were used for the calculations. The module efficiency of $12.39 \%$ cited by the manufacturer was used to calculate the power output of the panels from the received solar radiation.

Information on which model of the Grundfos SQFlex line of pumps was used for the water system was also unavailable. For the purposes of this analysis, the 40 SQF-3 model was assumed to be the pump used. This pump was selected for use in the analysis because it was the pump capable of pumping the design flow rates, at the design head, at the lowest wattages (see Figure 15 for the pump performance curves). 
$40 \mathrm{SQF}-3$

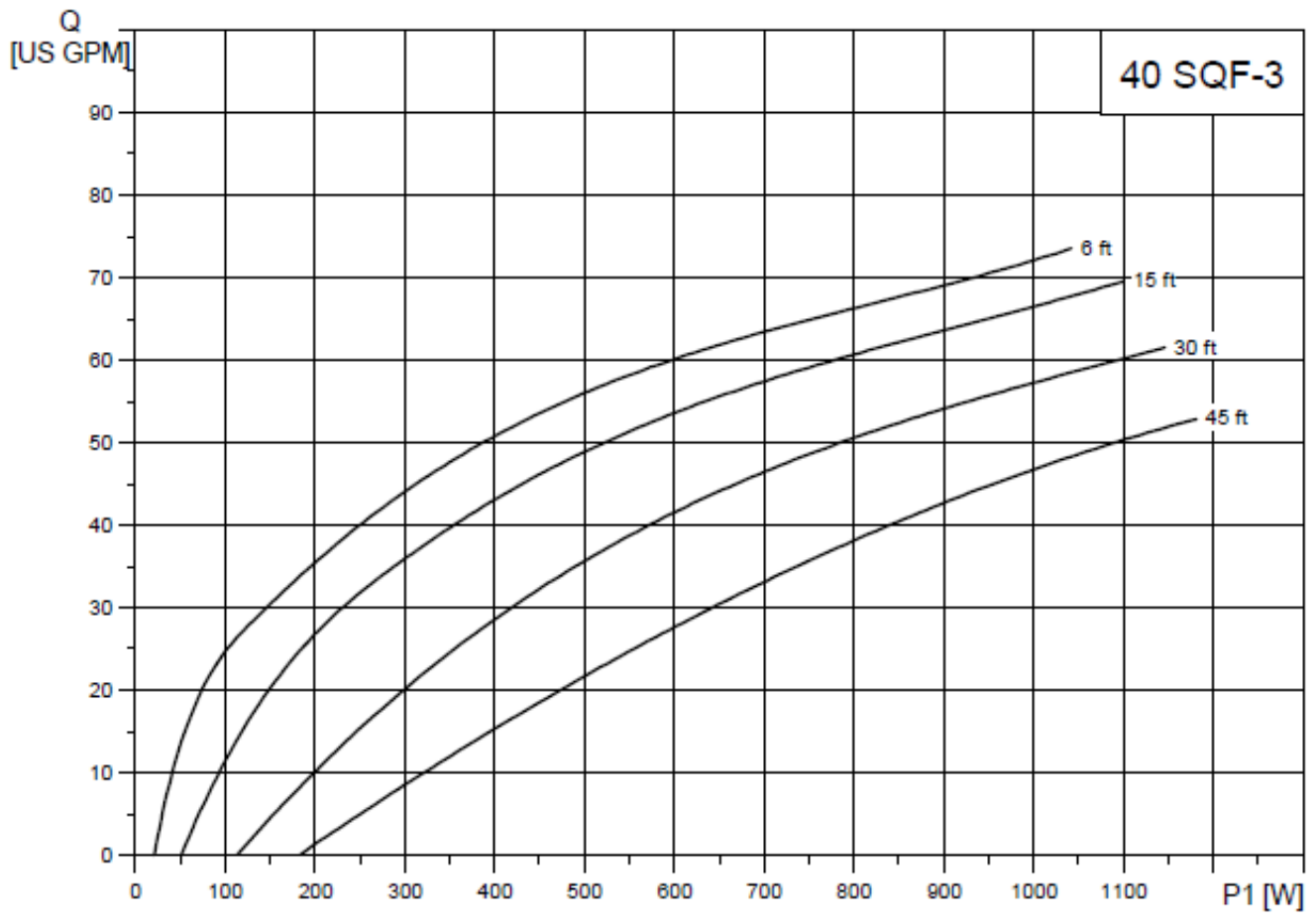

Figure 15. The pump performance curve for Grundfos pump 40 SQF-3 (from the Grundfos product guide).

The pump performance curves generated by the manufacturer for the SQFlex series pumps (Figure 15) differ from traditional pump curves (such as Figures 8 and 12) in that they do not directly relate head to flow rate but rather flow rate to wattage from the solar panel(s). Several curves are generated for each pump to show the relationship of flow rate to wattage at different heads. Conventional pump curves were created for various wattages (see Figure 16). The system head curve for the pump was calculated using the Hazen-Williams equation to estimate friction head losses for different flow rates. 




Figure 16. Potential System Operating Points for various wattages for pump model Grundfos 40 SQF-3.

The relationship between wattage and pump flow for the specified head was calculated by plotting the intersections of the system curve with the various power curves, and then fitting them with a trendline, as seen in Figure 17 below. 


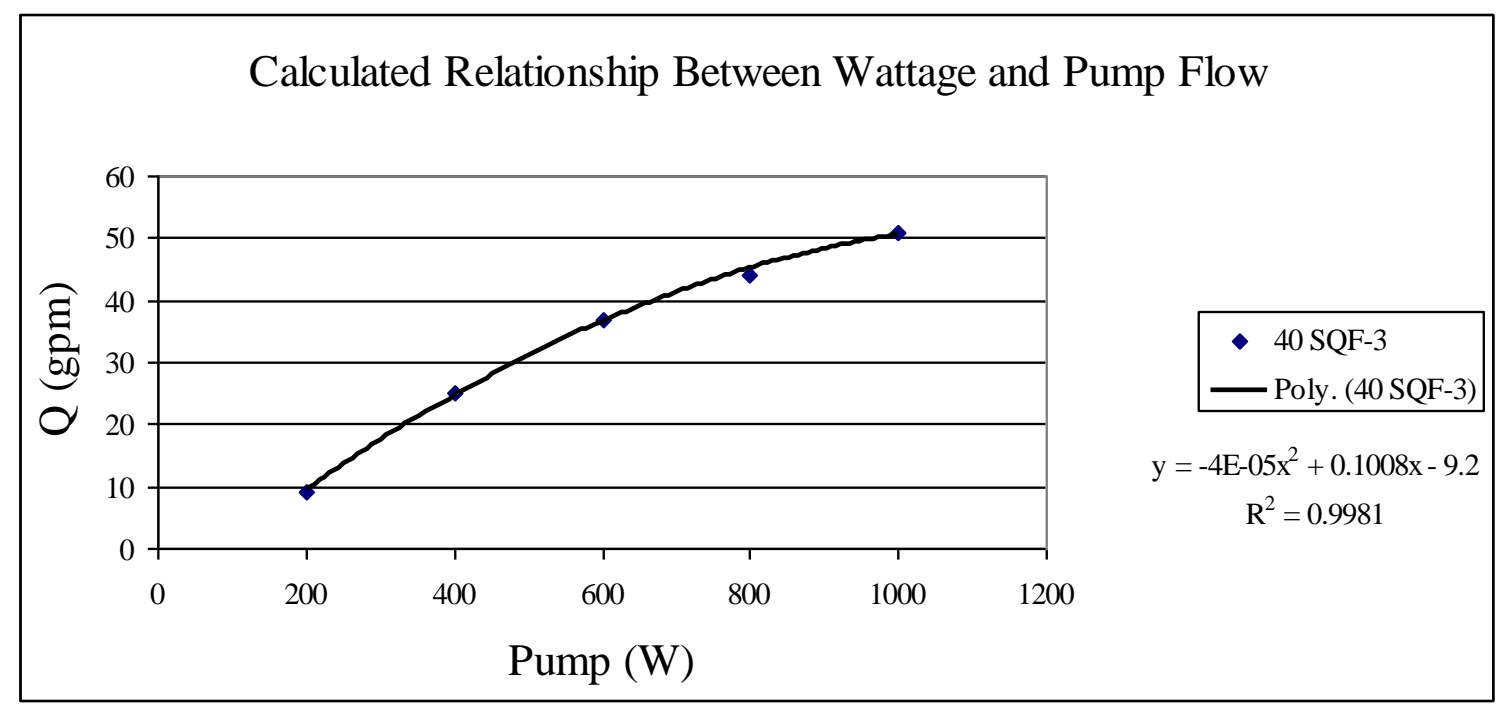

Figure 17. The calculated relationship between the wattage delivered to the pump and the resulting pump flow.

This relationship between wattage and pump flow was used to calculate pump flows throughout a day, using the solar panel power outputs estimated from solar radiation values, shown in Figure 18 below.

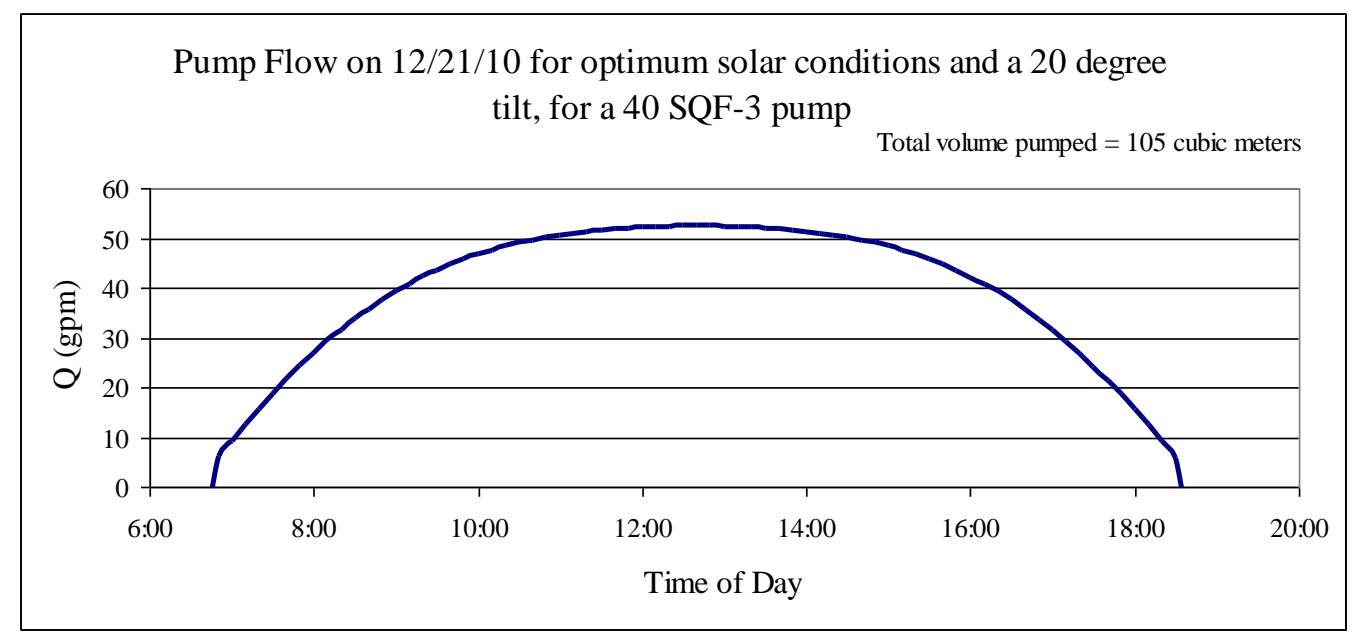

Figure 18. Calculated pump flow for the Grundfos 40 SQF-3 pump with an array of six solar panels at various times of day based on solar radiation received on 12/21/10.

Over the course of a perfectly sunny day, the $40 \mathrm{SQF}-3$ is capable of pumping $105 \mathrm{~m}^{3}$ of water, $116 \%$ of the design flow rate of $90 \mathrm{~m}^{3} /$ day per pump. However, cloud cover can have a large impact on the power output of solar panels. Even partly cloudy skies can significantly reduce the power produced. The system and the solar panel outputs were observed by the researcher twice, once on April 11, 2009, and once on July 11, 2010. On April 11, 2009, the power input for one pump was 460 Watts and 350 Watts for the other. On July 11, 2010 only one pump was operating, and its power input registered as 360 
Watts. Both times the observations were made at midday on partly cloudy days. The expected output for a sunny day at midday is 1040 Watts, meaning that the power generated on a partly cloudy day is only about $35 \%$ of that of a sunny day. The pump flow rates for partly cloudy conditions are shown in Figure 19.

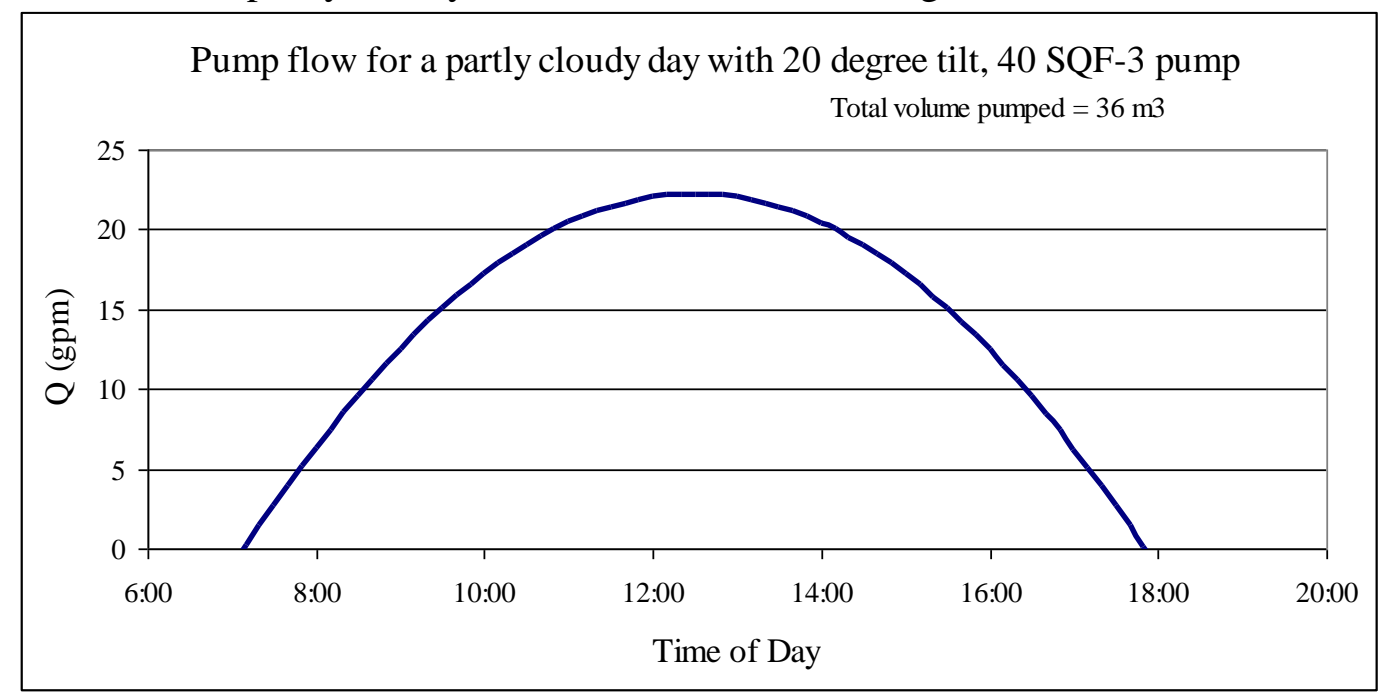

Figure 19. Flow for the Grundfos $40 \mathrm{SQF}-3$ pump and an array of six solar panels on a partly cloudy day.

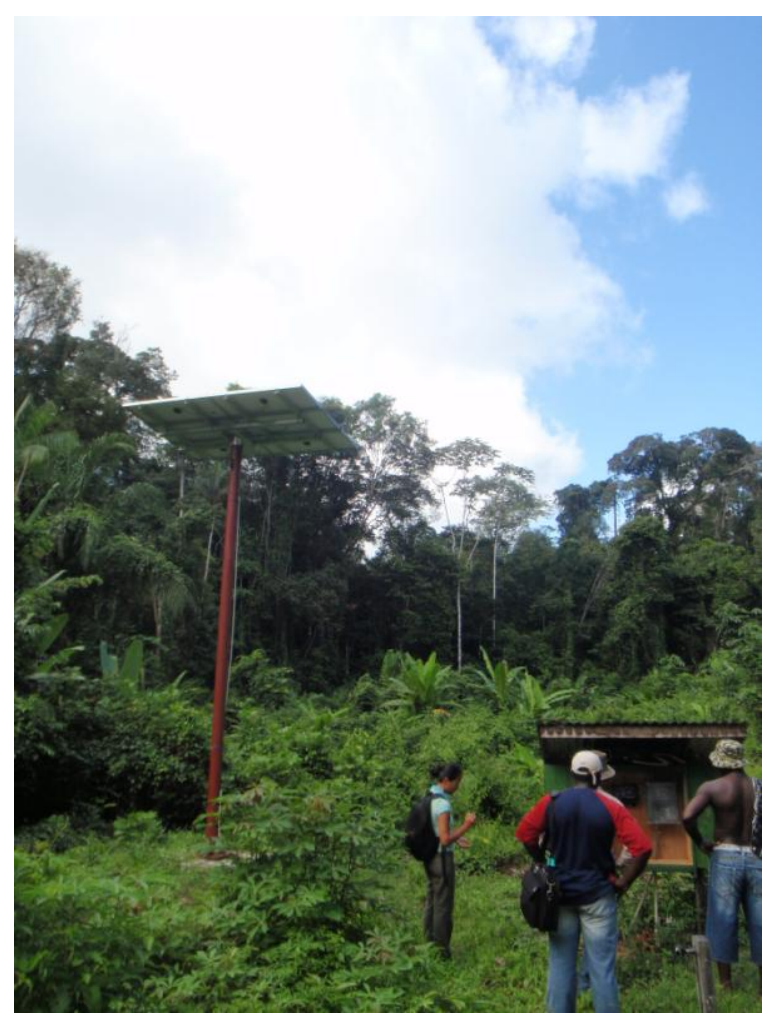

Figure 20. One of the solar panel arrays and cloud cover on April 11, 2009. 
The volume of water produced by the pump on a partly cloudy day is reduced from 105 $\mathrm{m}^{3}$ of water to $36 \mathrm{~m}^{3}$ (see Table 10). This is only $39 \%$ of the design volume of water pumped per day. On a completely overcast day, the volume of water pumped would be even further reduced. During the rainy season in Suriname it rains nearly every day, and the weather varies between partly cloudy and overcast. During the dry season it varies between partly cloudy and mostly sunny. It is rarely completely clear. A reduction of the solar panel output to just $10 \%$ of the optimum, as might happen on a very overcast day, would reduce the volume of water pumped over the day to just $0.5 \mathrm{~m}^{3}$.

Table 10. Water available per person at various operating conditions.

\begin{tabular}{lll}
\hline $\begin{array}{l}\text { solar panel output as } \\
\text { percent of optimum }\end{array}$ & $\begin{array}{l}\text { volume of water } \\
\text { pumped per day, two } \\
\text { pumps }\left(\mathrm{m}^{3}\right)\end{array}$ & $\begin{array}{l}\text { water per person } \\
\text { (liters/day) }\end{array}$ \\
\hline $100 \%$ & 105 & 84 \\
$35 \%$ & 36 & 28.8 \\
$10 \%$ & 0.5 & 0.4 \\
\hline
\end{tabular}

\subsubsection{Community Perceptions}

The majority of community responses centered on the poor performance of the water system (see Table 4). Participants responded not only that supply was insufficient and irregular but that it was also dirty. Few participants articulated a position about willingness-to-pay, with most of them evading answering the question directly. In the context of the interviews, this indicates unfamiliarity with the topic rather than an aversion, which is not surprising in the community context, where no payments outside of the original capital contribution have ever been collected or even requested. Many participants felt that village leadership was responsible for the water system, but for male participants this responsibility was also split with the project donors.

Another notable result of the community perception interviews in Guyaba was the number of people who brought up that they drank river water in the dry season. Over half of the participants mentioned that in the dry season they either drank river water or dug potholes in the riverbank to create small seeps from which they collected water. No one in either of the other two communities mentioned this, and a few people in the other communities specifically noted that neither they nor anyone else in their community ever drank river water.

\subsubsection{Sustainability Assessment - Guyaba}

The details for scoring the sustainability factors are provided in Appendix D. The results were compiled into final scores and are listed in Table 11. The scores for each element (row, column) can be as high as 4 , so a row or column can total as much as 20 to represent a maximum potential for sustainability. For the community of Guyaba, the score of 37 out of 100 is known to a \pm 1 certainty for each element. By accounting for 
elements that already have their highest or lowest possible score, the possible range of scores for this audit is 21 to 58 out of 100 .

Table 11. The results of the sustainability assessment matrix (McConville and Mihelcic 2007) for Guyaba.

\begin{tabular}{|c|c|c|c|c|c|c|}
\hline \multirow[b]{2}{*}{ life stage } & \multicolumn{5}{|c|}{ sustainability factor } & \multirow[b]{2}{*}{ total } \\
\hline & $\begin{array}{l}\text { socio- } \\
\text { cultural } \\
\text { respect }\end{array}$ & $\begin{array}{l}\text { community } \\
\text { participation }\end{array}$ & $\begin{array}{l}\text { political } \\
\text { cohesion }\end{array}$ & $\begin{array}{l}\text { economic } \\
\text { sustainability }\end{array}$ & $\begin{array}{l}\text { environmental } \\
\text { sustainability }\end{array}$ & \\
\hline $\begin{array}{l}\text { needs } \\
\text { assessment }\end{array}$ & 3 & 4 & 2 & 0 & 0 & 11 \\
\hline $\begin{array}{ll}\text { conceptual } & \\
\text { designs } & \text { and } \\
\text { feasibility } & \end{array}$ & 2 & 4 & 4 & 0 & 0 & 8 \\
\hline $\begin{array}{ll}\text { design and } \\
\text { action planning }\end{array}$ & 4 & 3 & 0 & 1 & 1 & 9 \\
\hline implementation & 3 & 1 & 2 & 1 & 1 & 8 \\
\hline $\begin{array}{l}\text { operation and } \\
\text { maintenance }\end{array}$ & 0 & 0 & 1 & 0 & 0 & 1 \\
\hline total & 12 & 12 & 9 & 2 & 2 & 37 \\
\hline
\end{tabular}

Socio-cultural respect: Unlike the water projects of Abenaston and Kayapaati, which Peace Corps volunteers helped coordinate, this project originated with and was planned by people from the community of Guyaba. It was started based on the community's own recognition of the importance of clean water and the difficulties they currently face in obtaining it. People from the community coordinated between the donors and the community, making it simple for the project process to respect traditional roles. The water project had the same successes and failings as the water project in Abenaston for the implementation and operation and maintenance stages. See Abenaston's sustainability audit for details.

Community Participation: Guyaba scored stronger than either Abenaston or Kayapaati in the area of community participation, especially in the initial project stages. Community participation was one of the strongest areas of the project, with the project initiated by consensus of the community. The project design was presented and thoroughly discussed with community members, and lines of communication between the community and the donors were clear. Although not involved in creating the action plan for the project, there was community approval of the design. However, the strong participation from the community during the first stages of the project began to disappear in the later stages. The building contractor did involve the community in every design decision or changes made after approval of the initial design, and no official management plan was created for the water system. In the current operation and maintenance stage there is no longer a water committee overseeing decisions made regarding the system, there are no people routinely performing any maintenance duties, and the system is not controlled by anyone. 
Outside of helping with the community's contribution, women have been minimally involved. There were no women on the water committee.

Political Cohesion: This project was administered in the same manner as Abenaston. See Abenaston's sustainability audit for details

Economic Sustainability: This project was administered in the same manner as Abenaston. However, in the operation and maintenance stage of the project, the community came to believe that the Rotary Club - Paramaribo or the building contractor had misappropriated funds. A lack of a final budget review continued this misunderstanding. Although neither Abenaston nor Kayapaati had a final budget review, this lack had a much larger impact in Guyaba on the relationship between the donors and the beneficiaries. As the community never began collecting funds, there is no financing available for any maintenance costs or other contingencies. The process of financially managing the system never even began.

Environmental Sustainability: This project was administered in the same manner as Abenaston. However, small grey water flows in Abenaston and Kayapaati are manifested as significant environmental problems in the larger community of Guyaba. If the water system operated as planned, it would result in detrimental environmental impacts on the community and nearby bodies of water. The greatest environmental problem in the community, poor drainage and contamination of water sources from drainage, would have been exacerbated by this project. This fact was not recognized during the initial assessment stage, or designed for later. None of the many taps located throughout the community were coupled with a way to drain off the grey water. The taps that do work stand in fetid pools of water. With over 2500 people living within a square kilometer, standing pools of contaminated water can pose a significant health risk, especially to children. 


\section{Discussion}

A water supply system is an engineered solution, but one that is particularly dependent on its supporting social infrastructure. The community-managed water supply system model depends, as its name implies, on both technical and social infrastructure. The combination of methods used in this investigation revealed how the technical and the social aspects are important to the long-term sustainability of the three water supply systems that were reviewed.

In this investigation, the first requirement for a water system to be defined as technically adequate is that it meets the guidelines set by the World Health Organization for an improved water source. In order to qualify, the water sources feeding the pumps need to be protected. The water systems of Abenaston, Kayapaati, and Guyaba all fail to meet this requirement. The original intakes for Abenaston and Kajapaati both had gravel or sand filters, but these were both removed from the systems by the communities due to operational difficulties. The water source for the system in Guyaba is well-removed from the community, but this does not protect the water or guarantee that it will be suitable. One of the most common themes in the community perception surveys in Guyaba was that the water was dirty. One participant said the appearance of the water was sometimes "like tea with milk", especially after heavy rainfalls that flooded the spring with runoff.

The second requirement for technical adequacy is that the water system is capable of providing an adequate amount of water to the community. I used 21 liters/person/day as the minimum threshold of adequacy for the water systems. This provides for all cooking and drinking water needs for the day, as well as a few bathing needs. Clothes washing, dish washing, and the majority of bathing still need to be done using alternative water sources when this amount of water is available. Once again, all three community water systems fail to meet this requirement. However, it is only in one case where the root of this problem can be traced to a technical failure. In both Abenaston and Kayapaati, the source of this problem is due to social and cultural factors that were not accounted for during the water project process.

Determining the true cause of the inadequacy of the water systems required information obtained from all of the methods used in this study. The initial technical review of the water systems in Abenaston and Kayapaati did not reveal any design flaws that would prevent the systems from providing sufficient water supply. In both communities the pumps were in good working order and provided sufficient head, and there were no indications that distribution network was not working properly. However, despite the systems being in working order they were not being operated. A report issued by the government of Suriname had named a lack of community ownership as the cause for operation problems - however, at the time of the evaluation both communities had water committees who took responsibility for overseeing the systems and clearly assigned operation and maintenance men. This indicates that a lack community ownership is not the problem. 
The sustainability audits gave an overall picture of the strengths and weaknesses of the water projects, and the results of the audit highlighted how some of the shortcomings during the project process later manifested as operational problems. For all three communities, the water projects scored quite low in the area of economic sustainability, environmental sustainability, and operation and maintenance. For both Abenaston and Kayapaati, the nature of the projects resulted in small environmental effects that have had no impact on the operation of the system. The low scores in economic sustainability, however, are reflected in several ways in the current status of the water systems. In the sustainability audit, a high score in economic feasibility "implies that sufficient local resources and capacity exist to continue the project in the absence of outside resources" (McConville and Mihelcic 2007). A low score, then, implies that no measures were taken to make certain that the communities had the economic resources or capacity to maintain the finished system. Since the water systems in Abenaston and Kayapaati both use gasoline, the capacity of the community to provide continual inputs of resources is critical for their operation. The cost to run the water systems daily, long enough to provide for minimum household water needs, amounts to approximately $\$ 40$ per year, per adult community member. However, the median yearly income of Maroon women in Suriname is also just $\$ 40$ a year (Heemskerk et al. 2004). If the community chose to run the system for just one month out of the year, the costs would still amount to more than ten percent of a woman's yearly income.

The responses of community members in Abenaston and Kayapaati in the community perception surveys provide greater insight into the problem of economic sustainability, as does cultural context from ethnographic work. One of the most common responses during the surveys, for both communities, was that providing gasoline to run the pump was a difficulty. Two other common responses were that they did not have money, and that they did not have work. The monthly cost to the community members to run the pump is a trifling sum by Western standards - just $\$ 1.80$ a month. However, in the context of Saramaka society, this sum can be quite burdensome. The gender roles in place in the Saramaka economy have resulted in placing the men in the position of primary wageearner, while the women produce most of the food with their farms. This means that women have scant opportunities to obtain cash on their own. In addition to that, the custom of married men and women maintaining separate households means that women's households often have very limited access to cash even through marriage. The neat, nice appearances of the Saramaka communities belie how cash-poor many of the households are. Most of the support that female-headed households receive comes in the form of goods such as soap, pots, cloth, matches, and not cash. Unmarried, divorced, or widowed women may have no access to cash or outside goods at all, and are forced to maintain themselves with what they bring out of the jungle with sweat and ingenuity. In Saramaka communities the problem of economic sustainability is fundamentally tied to gender. The gendered nature of the problem can be seen in the perception survey responses. In Abenaston, all of the men cited providing gasoline as a problem, but less than half of the women did. However, two thirds of the women mentioned the lack of wage-work available to them, as opposed to just $17 \%$ of the men who brought it up. The inability of women to provide the cash necessary to run the water systems is especially important 
because women often outnumber the men present in the communities by three to one. This problem of economic sustainability becomes clear when placed in context through the sustainability audits, the community perception surveys, and ethnographic information.

When we look back at Guyaba, the methods of technical review, sustainability audits, community perception surveys, and ethnographic information are important here as well in revealing the underlying causes of poor water system performance. Unlike Abenaston and Kayapaati, the technical review did not show the water system in Guyaba to have an appropriate technical capacity.

Instead of using a gasoline generator, the system in Guyaba uses arrays of solar panels to power the water pumps. While the use of solar panel eliminates the need for constant cash inputs to operate the system, it also presents other challenges. Foremost of these challenges is the cloudy nature of the tropical Surinamese climate. Under optimal, sunny conditions, the arrays are capable of producing power sufficient for the pumps to provide three times the minimum daily household water needs. However, clouds drastically reduce the power output of the solar panel arrays. On the two separate, partly cloudy days when the system was examined, the solar panels were seen to be producing less than a third of the theoretical maximum output. On a completely overcast day the power output might be reduced by more than $90 \%$. However, the poor technical performance of the water system has been exacerbated by the community response. Guyaba is the only community of the three which no longer had an active water committee at the time of the evaluation. It is also the community which showed the least amount of general knowledge about their system by community members. Both of these things are notable because Guyaba scored higher than both Abenaston and Kayapaati in community participation in the sustainability audits of the water project.

This lack of current community participation is likely because in Guyaba, the biggest problem with the water system is a technical flaw that the community has no control over. This has greatly eroded community support for the system. In Abenaston and Kayapaati, the communities see increased benefits for increased efforts to support their system. However, in Guyaba, all the efforts that the community made to improve the water system performance has only reduced it. For example, some community members from Guyaba coupled the pumps directly to the distribution network, bypassing the higher elevation storage tank in an attempt to improve flow. The result of this is that the majority of the taps in the community have gone permanently dry. The common themes in the community perception surveys are centered about poor water system performance: the water is dirty, the water is not enough, and the water does not reach all taps.

It is likely that gender roles have also played a role in Guyaba's water system. In the perception surveys, $100 \%$ of the men surveyed placed responsibility for the water system on the project donors, as opposed to less than a third of the women. In contrast to this, $73 \%$ of the women said that village leaders were responsible. This indicates two things. First, it shows that the women of the community are not aware that the poor performance of the water system is due to its construction, and out of the scope of community 
members to address. Second, the assignation of responsibility to village leaders reflects the origins of the water project. The water project in Guyaba was originated by a community-based NGO and administered entirely through traditional village power structures. This effectively eliminates the participation of women in any part of the project process except for the community's labor contribution during construction. While in Kayapaati the women eventually took over the water system themselves to get it running again, in Guyaba the women have so far done nothing to stop the deterioration of the water system or to contribute to its maintenance. This is despite a widespread appreciation of clean water, and despite Guyaba having the greatest need for clean water resources. Although it is possible that at some point the women may mobilize, at the time of the evaluation the women were still passing the responsibility over to the village leaders, to the men.

\subsection{Future Water Systems:}

For all three community water systems, the problems with the water systems might have successfully been addressed if there had been sufficient support for the communities in the final stage of the water projects: operation and maintenance. In the communitymanaged model for water systems, operation and maintenance is usually the provenance of the community. However, evaluation and measurement of project objectives might have resulted in additional support for the communities until the issues were resolved.

In all three communities, the greatest impediment to the success of the water systems was the power source. In Abenaston and Kayapaati, the cost of running gasoline generators was prohibitively expensive, and in Guyaba the solar arrays were insufficient. One possible way to address this would be to request the national government to subsidize the cost of fuel, so that funds raised by the community could support the operation and maintenance men. The government has a precedent of supporting a few water systems in the region (including Guyaba) by paying a salary to operation and maintenance men. However, the government already provides bi-monthly shipments of diesel fuel for village generators in all three communities. Additionally, while fuel must be paid for continually, operation and maintenance men might be paid by the community once or twice a year. Since actually collecting the funds from community members is one of the most labor-intensive tasks of running the water system, this would considerably lighten the responsibilities of the water committee. Alternatively, several community members from Abenaston suggested that the gasoline generator be eliminated entirely, and that the pump be hooked up to the village generator.

Solar panels may still be a viable power source for future water systems, however, care must be taken that the array is adequately sized to provide sufficient power even on partly cloudy or cloudy days. This should be coupled with water tanks sized adequately to provide enough storage for the water supply to last through the evening and early morning, which are both peak water use times. 
Another key factor for sustainability of the water systems is the involvement of women community members, from the very start of the water project. Women have small roles in traditional Saramaka leadership, however, one out of every four officially appointed village elders (basia) is a woman. These women basia are particularly responsible for those things in community affairs that are women's responsibilities. Since water management is also recognized as a responsibility of women, it should not be difficult for outside organizations to help encourage female participation in such a manner that the male leaders also encourage and endorse it. In Abenaston and Kayapaati where there was greater female involvement, the water systems have shown to be more resilient in the face of many other challenges.

In addition to improved power sources and female involvement, future water systems should be built recognizing that Saramaka communities have access to many alternative water sources. One of the foremost of these is rainfall. All Saramaka women surveyed for this investigation reported using rain as their primary source of drinking water during the rainy season. Increasing the communities' ability to effectively catch and store rainwater reduces the communities' reliance on a system that they may not have the capacity to repair quickly. Also, by recognizing that the communities' have an acceptable source of drinking water for eight months of the year and planning to use this would allow the communities to conserve time and resources towards operating the water systems in the times of greatest water scarcity.

Finally, any future water systems should also be evaluated after completion. The evaluation of the three community water systems has shown that complex interactions between culture, society, and the technical design of the water system can have significant impacts on their long-term sustainability. The use of the sustainability audit in future evaluations would provide a somewhat objective framework for these evaluations. Community perception surveys might also be valuable in finding underlying reasons for poor performance. The results of this investigation showed that the communities' were able to accurately identify the problems they were having with their own water systems. Lastly, ethnographic information about the communities should be used, as it has provided valuable insight into how the water systems are integrated into existing communities. 


\section{Conclusions}

Both objectives of this investigation were met. First, the current status and past performance histories of three, community-managed, rural water supply systems in Saramaka communities were determined with a combination of quantitative and qualitative methods and the use of a sustainability auditing tool. These results indicated that success or failure of a water system was not determined by just one factor, nor was it straightforward to define what a successfully operating water supply system looked like.

The second objective was to compare the roles of technical adequacy and social factors in determining the long-term sustainability of water supply systems. I determined that technical adequacy of the water supply system was critical to its sustainability. Several other sustainability factors, including economic feasibility, community support, and the involvement of women in the project process were also critical to sustainability. Those communities with strong community support and involvement of women were able to overcome difficulties resulting from extended breakdowns to revitalize their water systems. However, even in those communities with strong internal support for the water supply systems and which were technically sufficient, the real operation and maintenance costs were unaffordable for the community. Also, if women were not initially a part of the water project process, gaining involvement in the water supply system management in one case required going against traditional gender roles and subverting traditional community authorities. This may lead to future losses in community support for the water supply system.

In terms of satisfying the MDG guidelines for improved sources of drinking water, all three systems are failures. Successful operation of a water supply system does not guarantee that the water it supplies will be clean or improved. Major obstacles exist for the construction of sustainable water supply systems in Saramaka communities. One obstacle is the lack of a suitable power source. Gasoline-powered pumps are prohibitively expensive, but climatic conditions are unfavorable for solar power. Another obstacle to water system sustainability is the vulnerability of the water systems to breakdowns. Based on the past performance of the water systems, it is likely that any breakdown in the water system will render it inoperable for extended periods without outside intervention. Unless these issues can be addressed, alternative interventions such as source protection (e.g., springboxes) or rainwater collection systems may be better able to provide reliable sources of clean drinking water to Saramaka communities. 


\section{References}

(2008). Upper-Suriname Water Project Proposal: Community Participation for more Sustainability: Scaling-up the Botopasi Model. M. o. N. Resources. Paramaribo, Government of Suriname.

Ferguson, A. (2005). Water Reform, Gender, and HIV/AIDS: Perspectives from Malawi. Globalization, Water, \& Health: Resource Management in Times of Scarcity. L. Whiteford and S. Whiteford. Santa Fe, School of American Research Press.

Gunatilake, H., J.-C. Yang, et al. (2007). Good Practices for Estimating Reliable Willingness-to-Pay Values in the Water Supply and Sanitation Sector. ERD Technical Note Series No. 23. Manila Phillippines Asian Development Bank: 63.

Heemskerk, M., A. Norton, et al. (2004). "Does Public Welfare Crowd Out Informal Safety Nets? Ethnographic Evidence from Rural Latin America." World Development 32(6): 941-955.

Hijmans, R., N. Garcia, et al. (2009). "Georeferenced administrative areas of Suriname." Retrieved 3/31/11, 2011, from www.gadm.org.

IDB (2008). Water Supply Suriname Master Plan, International Development Bank.

Isham, J. and S. Kähkönen (1999). "What Determines the Effectiveness of CommunityBased Water Projects? Evidence from Central Java, Indonesia on Demand Responsiveness, Service Rules, and Social Capital." World Bank Social Capital Initiative Working Paper Series(14).

Kleemeier, E. (2000). "The Impact of Participation on Sustainability: An Analysis of the Malawi Rural Piped Scheme Program." World Development 28(5): 929-944.

Kleemeier, E. (2001). "The Role of Government in Maintaining Rural Water Supplies: Caveats from Malawi's Gravity Schemes." Public Administration \& Development 21(3): 245-257.

LeCompte, M. D. and J. P. Goetz (1982). "Ethnographic Data Collection in Evaluation Research." Education Evaluation and Policy Analysis 4(3 (Autumn, 1982)): 387-400.

McConville, J. (2006). "Applying life cycle thinking to international water and sanitation projects: An assessment tool for project managers in sustainable development work." $\underline{\text { M.S. }}$ Research Report Retrieved April 11, 2011, from http://cee.eng.usf.edu/peacecorps/5\%20\%20Resources/Theses/Assessment/2006Mcconville.pdf. 
McConville, J. R. and J. R. Mihelcic (2007). "Adapting Life-Cycle Thinking Tools to Evaluate Project Sustainability in International Water and Sanitation Development Work." Environmental Engineering Science 24(7): 937-948.

Morrison, M. D., R. K. Blamey, et al. (2000). "Minimising Payment Vehicle Bias in Contingent Valuation Studies." Environmental and Resource Economics 16(4): 407-422.

PAHO (2010). "Pan-American Health Organization (PAHO) Basic Health Indicator Database." Retrieved 11-18-2010, 2010, from http://www.paho.org/english/dd/ais/cp_740.htm.

Price, R. (1974). Saramaka Social Structure: Analysis of a Maroon Society in Surinam. Rio Piedras, Puerto Rico, Institute of Caribbean Studies.

Price, R. (1983). First-Time: The Historical Vision of an African American People. Chicago The University of Chicago Press.

Price, R. (2001). Preface to Second Edition of First-Time. First-Time: The Historical Vision of an African American People. Chicago, University of Chicago Press.

Price, R. (2011). Rainforest Warriors: Human Rights on Trial. Philadelphia, University of Pennsylvania Press.

UN (2009). The Millenium Development Goals Report 2009. New York, United Nations.

Whittington, D., J. Davis, et al. (2009). "How well is the demand-driven, community management model for rural water supply systems doing? Evidence from Bolivia, Peru and Ghana." Water Policy 11(6): 696.

WHO (2011). "World Health Organization (WHO) Statistical Information System." Retrieved 3-19-11, 2011, from http://www.who.int/whosis/indicators/compendium/2008/2wst/en/. 